\title{
The Distribution of the Fauna in the Interstitial Habitats of Riverine Sediments of the Danube and the Piesting (Austria)
}

\author{
by \\ Dan L. DANIELOPOL
}

\section{INTRODUCTION}

The Danube, $2900 \mathrm{~km}$ in length, is the second longest european river. It is commonly divided in 3 sections: the upper Danube, middle Danube and lower Danube (see Fink, 1967). In Austria (upper Danube section) the river flows in an area varying in altitude between $293 \mathrm{~m}$ (Passau) and $139 \mathrm{~m}$ (Hainburg), and it is a typical mountain river, receiving a large amount of water from the Inn tributary (Liepolt, 1961).

Water flow and erosion are strong; large amounts of sand, pebbles and gravel are carried and redeposited downstream in quiet sites near the shores where they form large sediment banks; water turbidity is high. The water level varies markedly up to 8 meters during the year; in the later part of the summer, in autumn and winter it drops and large sediment banks are exposed (this is especially noticeable in Lower Austria, downstream from the Ybbs-Persenbeug dam-lake).

The aquatic interstitial fauna living in the riverine sediments of the Danube was investigated in the Federal Republic of Germany by Schwoerbel and ecological and faunistical results were published by this author (1959a, 1959b, 1961a, 1961b, 1962, 1964a, b, 1967), Löffler (1961), and An der Lan (1962), in Czechoslovakia by Ponyi and Ponyi (1961) and also by Andrassy (1962), in Hungary by Dudich, Laszloffy (informations in Schwoerbel, 1967) and Andrassy (1962), in Romania by Motas and coworkers (1947) and also by Orghidan and Dumitrescu (informations in Schwoerbel, 1967). In Austria Vornatscher $(1938,1974)$ only gave some faunistical information concerning the riverine interstitial fauna of the Danube in several springs emerging in the bed of a dead arm of the Danube (Lusthauswasser) near the Prater in Vienna.

Schwoerbel (1964b and 1967) reviewed the data concerning the interstitial

*) Limnologisches Institut, Österr. Akad. d. Wissenschaften. Berggasse 18/19 Wien A-1090. 
fauna inhabiting the superficial groundwater of riverine sediments of the Danube (Die hyporheische Fauna). He pointed out that the "hyporheic fauna" of the Breg and Brigach in the Black Forest is qualitatively and quantitatively very rich (many water mite species, high numbers of harpacticoids and insect larvae as well as several hypogean isopods, cyclopoids and ostracods). The hyporheic fauna in the middle and lower Danube sections is qualitatively much poorer, according to the information of Dudich and Orghidan (Schwoerbel, 1967); i.e. the water mite fauna is very meager and only few hypogean species have been encountered, e.g. the nematode Chromadorina berczeki Andrassy and the gastropod Hohenwarthia orghidani Grossu; no quantitative data are available for the interstitial fauna occurring within these two Danube sections.

In 1973, Professor H. Löffler (Limnological Institute of the Austrian Academy of Sciences) suggested a research program on the interstitial habitats of the riverine sediments of the Danube between Ybbs-Persenbeug and Hainburg (Lower Austria), as the habitats remain practically uninvestigate in this area up to date and are submitted to different degrees of pollution. The differences between the interstitial fauna of the riverine sediments of the Danube and those of the Danube Valley (occurring in wells in typical groundwater) are of interest as the river is sometimes highly polluted.

This project was also started since, in the next few years, most of the exposed sediment banks of the Danube will disappear due to the construction of several hydroelectric power-plants with dam-lakes.

For comparative purposes the interstitial fauna of another polluted stream, namely Piesting, was also investigated. As the project is very extensive, cooperation with several other institutes and colleagues was necessary.

For the field investigations I received assistance from the Österreichische Donau Kraftwerke (Dipl. Ing. Schimunek), from the Nieder-Österreichische Landesregierung (Dr. Weninger), from the Magistrat Wien (Dipl. Ing. Leiner, from the Wasserwerke Department, Prof. Dosch, Dr. Jaksch and Dr. Locker, from the Hygiene Anstalt). Several colleagues made faunistical identifications of the material other than ostracods: Prof. Dr. Schwoerbel (University of Frieburg/Brig); Dr. Sket (University of Ljubljana); Prof. Dr. Löffler, Dr. Schiemer, Dr. Humpesch, Cand. phil. Eder (Limnologisches Institut, Wien). Several people made technical suggestions on problems of hydrogeology and sampling methods: Dr. Nusbaumer (BUFA-Arsenal, Wien); Dr. A. Mangin, Dr. R. R. Rouch, Dr. Bakalowich (Laboratoire Souterrain du C.N.R.S., Moulis); Dr. Hacker (Limnologisches Institut, Wien). The following colleagues helped the author during field trips: Dr. Jungwirth, Dr. Newrkla, Cand. Phil. Glatz, Cand. phil. Gross, Mr. Lanzenberger. Mr. Aigner (Biologische Station, Lunz) constructed an apparatus for sampling groundwater. The bacteriological analyses were performed by the staff from the Hygiene Anstalt, Wien (Dr. Jaksch and Dr. Locker). A "Theodor Körner-Stiftungsfonds" grant was received for the completion of the research program carried out during 1975. Miss Susan Powell improved the English form of the text.

To all these people and institutions the author expresses his gratitude.

\section{SAMPLING SITES AND METHODS}

The interstitial fauna of riverine sediments was sampled mainly using the method of Bou and Rouch (1967), by pumping the groundwater with a hand pump. The method of Karaman and Chappuis (by digging holes) was also used 
in some cases. The first method allows collection of water from the deeper as well as the superficial layers. I used a stand pipe which has a perforated stretch of $20 \mathrm{~cm}$ length situated at $7 \mathrm{~cm}$ from the apex with holes of $5 \mathrm{~mm}$ diameter ( 5 raws). For quantitative samples 10,60 or 120 liters were pumped out and each ten liters were filtered through a $80 \mu$ mesh plankton net and fixed in formaldehyde. For comparative purposes water samples from the river near the riverine banks were collected (fig. 1, 2, 4 and Tables 1 and 2). For the interstitial fauna living in the wells, the Cvetkov sampler modified by Danielopol and Dancau similar to that described by Bou (1974) was successfully used (when qualitative samples were collected). For Norton pumps, the water was directly filtered through a plankton net $(50 \mu$ or $80 \mu$ mesh).

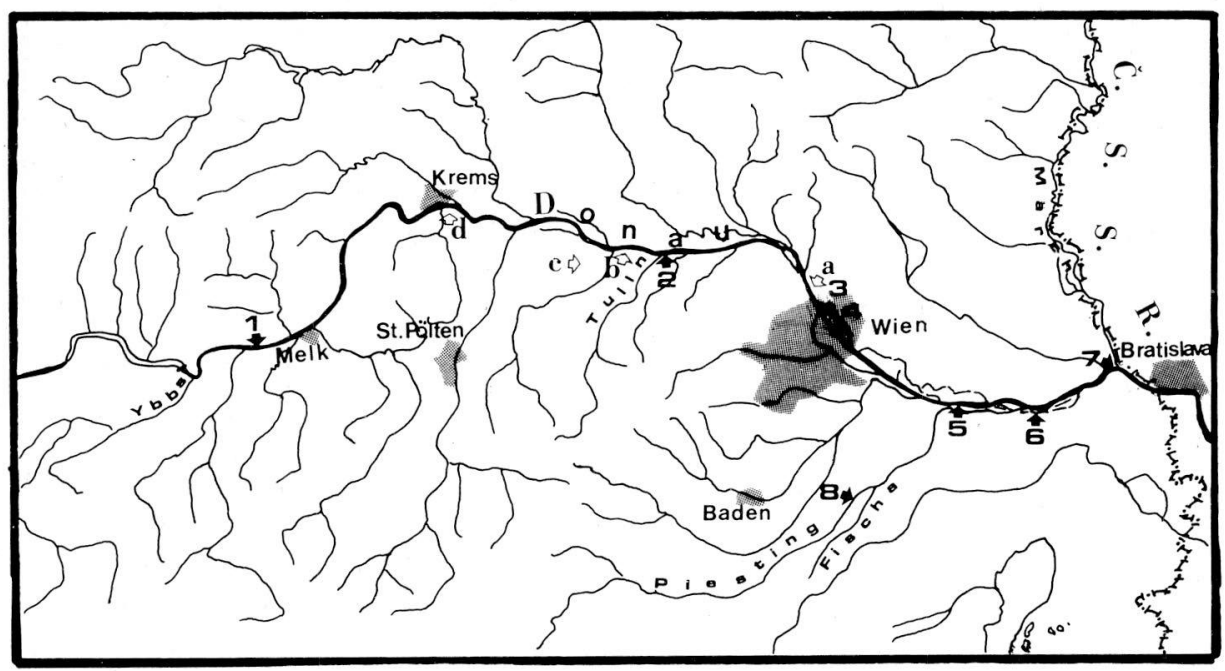

Fig. 1. The location of the different sampling sites in Lower Austria. Numbers indicate the riverine sample sites; the letters the main areas where well fauna were investigated; $(1$ - Ebersdorf (Melk), km-2041 (L); 2 - Tulln, km-1963-5 (R); 3 - Wien 1 (Floridsdorf), km-1932.2 (L); 4 - Wien 2 (Reichsbrücke), km-1929.3 (L); 5 - Fischamend, km-1908.9 (R); 6 Wildungsmauer, km-1892.5 (R); 7 - March, km-1880.2 (L); Wells a - Wien (north from Floridsdorfbrücke); b, c - Tulln area; d - Thallern (Krems) area).

To estimate the efficiency of the Bou-Rouch pump for quantitative samples of different groups of animals I quantified the fauna for each ten liters. The first 10 liters are the most productive for the nematodes, the oligochaetes and harpacticoids. The abundance of these groups decreases markedly in the fol- 


\begin{tabular}{|c|c|c|c|c|c|c|c|c|}
\hline$A$ & $B$ & $C$ & $D$ & $E$ & $F$ & $G$ & $H$ & 1 \\
\hline & DONAU & & & & & & & \\
\hline & 2041, & $L$ & $\begin{array}{l}\text { Ebersdorf } \\
\text { Melk b, D.. }\end{array}$ & $\begin{array}{l}025 \\
020 \\
\end{array}$ & 2.09 .73 & $\stackrel{S H}{P J}$ & $\begin{array}{l}0.3-0.4 \\
1.15\end{array}$ & 150 \\
\hline 1 & $-\ldots-$ & $-11-$ & -11 & $\begin{array}{l}030 \\
031\end{array}$ & $-\ldots-$ & $\left.\begin{array}{c}S H \\
P\end{array}\right]$ & $\begin{array}{l}0.3-04 \\
1.30\end{array}$ & $-\cdots-$ \\
\hline & $-\cdots-$ & $-\infty$ & -1 & $\begin{array}{l}019 \\
014\end{array}$ & \begin{tabular}{|c|}
7.10 .73 \\
\end{tabular} & $\begin{array}{l}P \\
P\end{array}$ & $\begin{array}{l}0.50 \\
1.00\end{array}$ & $\begin{array}{l}-\cdots- \\
-\cdots-\end{array}$ \\
\hline 2 & 1963.5 & $R$ & Tulln & $\begin{array}{l}014 \\
024 \\
023\end{array}$ & 25.09 .73 & $\left.\begin{array}{l}P_{3} \\
P\end{array}\right]$ & $\begin{array}{l}1.00 \\
0.57 \\
1.30\end{array}$ & $-10-$ \\
\hline \multirow[b]{2}{*}{3} & 1932,2 & $L$ & $\begin{array}{l}\text { Wien-1 } \\
\text { (Floridsd.) }\end{array}$ & $\begin{array}{l}004 \\
013\end{array}$ & \begin{tabular}{|l|}
27.09 .73 \\
29.09 .73 \\
\end{tabular} & \begin{tabular}{|l}
$P$ \\
$P$
\end{tabular} & $\begin{array}{l}0.50 \\
1.00\end{array}$ & $\begin{array}{c}2 \\
-\cdots-\end{array}$ \\
\hline & $-" 1-$ & -נינ- & $-\cdots-$ & $\begin{array}{l}\text { Wien-sh } \\
\text { Wien-P }\end{array}$ & 30.08 .73 & $\mathrm{SH}_{\mathrm{P}}$ & $\begin{array}{l}0.3-0.4 \\
1.15\end{array}$ & 9 \\
\hline \multirow[b]{2}{*}{4} & 1929.3 & $L$ & \begin{tabular}{|} 
Wien-2...a \\
Reichsbr)
\end{tabular} & $\begin{array}{l}028 \\
029\end{array}$ & 18.09 .73 & $P$ & $\begin{array}{l}0.45 \\
1.15\end{array}$ & $\begin{array}{l}0.50 \\
-\cdots-\end{array}$ \\
\hline & & $-\cdots-$ & $\begin{array}{l}\text { Wien-2 "b. } \\
\text { Reich sbr.s }\end{array}$ & $\begin{array}{l}015 \\
016\end{array}$ & 2.11 .73 & $P_{P}$ & $\begin{array}{l}0.60 \\
1.20\end{array}$ & 2 \\
\hline 5 & 1908.9 & $R$ & Fischamen & $\begin{array}{r}1018 \\
017\end{array}$ & 29.10 .73 & {$\left[\begin{array}{l}P \\
P\end{array}\right]$} & $\begin{array}{l}0.63 \\
1.35\end{array}$ & 2.50 \\
\hline 6 & 1892,3 & $R$ & \begin{tabular}{|l|} 
Wildungs- \\
mauer
\end{tabular} & $\begin{array}{l}027 \\
026\end{array}$ & $\begin{array}{c}20.09 .73 \\
-\end{array}$ & {$\left[\begin{array}{l}P \\
P\end{array}\right]$} & $\begin{array}{l}0.50 \\
1.35\end{array}$ & 1 \\
\hline \multirow{3}{*}{7} & 1880,2 & $L$ & March „, $a$, & $\begin{array}{l}001 \\
003 \\
002 \\
010 \\
012\end{array}$ & $\begin{array}{c}28.09 .73 \\
+\end{array}$ & {$\left[\begin{array}{l}P^{\prime} \\
P \\
P \\
P \\
P \\
P \\
P\end{array}\right]$} & $\begin{array}{l}0.50 \\
1.35 \\
1.50 \\
2.40 \\
3\end{array}$ & 1.50 \\
\hline & $-\cdots-$ &..- & - & $\begin{array}{l}009 \\
00718 \\
006 \\
005 \\
011\end{array}$ & $\begin{array}{c}17.10 .73 \\
-\end{array}$ & נ] & $\begin{array}{l}0.50 \\
1.35 \\
1.95 \\
2.50 \\
3\end{array}$ & $-\cdots-$ \\
\hline & $-\cdots-$ & $-\infty$ & March „. b.. & $\begin{array}{l}032 \\
033 \\
034 \\
\end{array}$ & $\begin{array}{c}11.10 .74 \\
-\end{array}$ & $\left.\mid \begin{array}{l}P_{J} \\
P_{1} \\
P\end{array}\right]$ & $\begin{array}{c}0.75 \\
1.50 \\
3\end{array}$ & $-\cdots-$ \\
\hline 8 & PIESTIN & 勾 $R$ & $\begin{array}{c}\text { Moosbrund } \\
I I\end{array}$ & $\begin{array}{l}\text { Piest. } \\
-010\end{array}$ & 20.02 .75 & $P$ & $0.5-0.7$ & \\
\hline
\end{tabular}

Table 1. The list of sampling sites on the riverine banks of Danube and in the river bed of the Piesting (Lower Austria).

A - Number of the different stations (see fig. 1); B - Position of the stations according the Danube km.; C - Position of the stations according the Danube banks ( $\mathrm{L}$ - left bank, $\mathrm{R}$ - right bank); D - Name of the nearest locality (in breackage the common name used for the sample); $\mathrm{E}$ - Conventional notation of the sample; F - Date of the investigation; the water level of the 
Danube having tendency to decrease ( $\downarrow$ ) or to increase ( $\uparrow$ ); G - Method used (SH - KaramanChappuis holes; P - Bou-Rouch pump; cross lines indicate that the investigations at different depths were made in the same place); $\mathrm{H}$ - Conventional depth at which the groundwater was investigated (for the Bou-Rouch pump the depth is represented by the distance from the point of the tube till the surface of the beach; for the Karaman-Chappuis holes the depth is represented by the distance from the surface of the beach till the bottom of the hole); I - Distance from the river at which the interstitial system was investigated.

\begin{tabular}{|c|c|c|c|c|c|c|c|}
\hline A & B & C & D & $\mathrm{E}$ & $\mathbf{F}$ & G & $\mathrm{H}$ \\
\hline a & Wien & L & $\begin{array}{l}\text { North from } \\
\text { Floridsdorf- } \\
\text { brücke }\end{array}$ & $\begin{array}{l}\mathrm{F}_{1} \\
\mathrm{~F}_{2} \\
\mathrm{~F}_{3} \\
\mathrm{~F}_{4} \\
\mathrm{~F}_{5}\end{array}$ & $\begin{array}{c}17.06 .73 \\
-"- \\
31.08 .73 \\
-"- \\
-"-\end{array}$ & $\begin{array}{l}\text { PF } \\
-"- \\
\text { PF } \\
-"- \\
-"-\end{array}$ & $\begin{array}{l}250 \mathrm{~m} \\
400 \mathrm{~m}\end{array}$ \\
\hline $\begin{array}{l}b \\
+ \\
c\end{array}$ & Tulln & R & $\begin{array}{l}\text { Donau Chemie } 6 \\
\text { Danube km- } 1972 \\
\text { Dürnrohr } \\
\text { Kleinschönbich1 } \\
\text { zrontendorf a.d. } \\
\text { Donau } \\
\text { l.osbierbaum } \\
\text { Bärndorf } \\
\text { Kaindorf } \\
\text { Maria Ponsee } \\
\text { Oberbierbaum }\end{array}$ & $\begin{array}{l}\text { F-Donau } \\
\text { Chemie } 6 \\
\text { F-1246 } \\
\text { F-1250 } \\
\text { F-1262 } \\
\text { F-1266 } \\
\text { F-1272 } \\
F-1274 \\
F-1278 \\
F-1284\end{array}$ & $\begin{array}{c}22.11 .73 \\
-"- \\
-"- \\
-"- \\
-"- \\
-"- \\
-"- \\
\text { "- } \\
\text { "- }\end{array}$ & $\begin{array}{l}\text { AC } \\
-"- \\
-"- \\
-"- \\
-"- \\
-"- \\
-"- \\
-"- \\
-"-\end{array}$ & $\begin{array}{l}20 \mathrm{~m} \\
1.7 \mathrm{~km} \\
250 \mathrm{~m} \\
250 \mathrm{~m} \\
4.5 \mathrm{~km} \\
2 \mathrm{~km} \\
2.5 \mathrm{~km} \\
2.7 \mathrm{~km} \\
3.7 \mathrm{~km}\end{array}$ \\
\hline$d$ & $\begin{array}{l}\text { Thallern } \\
\text { (Krems) }\end{array}$ & $\mathrm{R}$ & $\begin{array}{l}\text { Danube km } 1997 \\
-"-1995.5 \\
-"-1996.5 \\
-"-1998\end{array}$ & $\begin{array}{l}F-1324 \\
F-1326 \\
F-1328 \\
F-1332\end{array}$ & $\begin{array}{c}12.11 .73 \\
-"- \\
-"- \\
-"-\end{array}$ & $\begin{array}{l}\text { AC } \\
-"- \\
-"- \\
-"-\end{array}$ & $\begin{array}{l}700 \mathrm{~m} \\
500 \mathrm{~m} \\
400 \mathrm{~m} \\
250 \mathrm{~m}\end{array}$ \\
\hline
\end{tabular}

Table 2. The list of the wells investigated in the Danube Valley in Lower Austria.

A - Number of the area investigated (see fig. 1); B - Conventional name of the area investigated; C - Position of the stations according to the Danube bank ( $\mathrm{L}$ - left bank, R - right bank); D Name of the nearest locality or Danube $\mathrm{km}$ number; $\mathrm{E}$ - Conventional notation of the sample; $\mathrm{F}$ - Date of the investigation; $\mathrm{G}$ - Type of wells; methods of investigation (Norton pump investigated by simple filtration of the water - PF; wells with diameter exceeding $0.50 \mathrm{~m}$, investigated with the Cvetkov phreatobiological net, AC); H - Distance from the Danube river at which the well is located. 
lowing samples (fig. 5, 6, 9, 10A, B). The largest amount of sediment, sand, silt and fine gravel also occurs in the first 10 liters (fig. 9F, G, H, I, J). These data suggest that the nematodes, oligochaetes and harpacticoids which are creeping forms and are closely associated with the substrate, are dislodged by the water flowdrainage only in the area near the stand pipe.

The cyclopoids, the isopods, the amphipods and the ostracods seem to be less dependent on the substrate and they are easily washed out by the flow of the water from remote areas. This can be well noticed (fig. 9) in the Melk station where 120 liters were pumped out and the fauna in the 1st, 7 th and 12th 10 liters was counted. From these investigations one can conclude that the first 10 liters are already representative of the community which exists around the stand pipe.

The 60 liters water and sediment are sucked from layers which most probably do not exceed $34 \mathrm{~cm}$ deep (it means $7 \mathrm{~cm}$ up and down around the perforated area of the pipe) according to Dr. Mangin's preliminary estimations (personal communication). This was partly confirmed in field sampling on the March station where the very turbid and black water occurring at $3 \mathrm{~m}$ depth was not sucked when the pipe was introduced at the $2.50 \mathrm{~m}$ horizont (only clear water without suspended material was obtained here).

In table 1 the conventional depth at which the groundwater was investigated is presented. For the Bou-Rouch pump the conventional depth is represented by the distance from the surface of the beach till the apex of the stand pipe. For convenience in the following discussion, I shall use only the conventional depth values at which the groundwater was investigated. A more precise estimation of the area from which the interstitial water comes is possible by using pump tests and dye tracer methods (Dr. Nusbaumer, personal communication).

The porosity and the permeability in deep layers of sediments are difficult to estimate without expensive devices. In most of the cases in the area investigated the riverine sediments are formed from pebbles, gravel, sand, silt and to a lesser extent, stones. The larger the amount of gravel, sand and silt between corse gravel, pebbles and stones, the lower is the degree of sorting, and the smaller is the effective porosity* and permeability. In sediments with a low permeability the water velocity is slow and the specific conductance of the water (electric conductivity, due to the salts in solution) is high. From the amount of sediment (fine gravel and sand) sucked out in the first 10 liters with the Bou-Rouch pump and from the values for the electric conductivity of the interstitial water, it is possible to obtain an idea on the magnitude of the porosity and the permeability of the interstitial system, in different sediment layers (fig. 7). This information is useful for determining faunal distribution.

The compaction of the sediments was estimated from the difficulties of inserting the pipe within the sediment.

The oxygen concentration was measured with electrodes of an oxygen meter YSY-64 Yellow Spring (mean error $\pm 0.16 \mathrm{mg} / \mathrm{l}$ ) directly in the stand pipe

* see also Castany, 1963. 
after short pumping tests which allowed elimination of the water introduced from outside. In a new type of stand pipe the holes are closed with a plug similar to those described by Williams and Hynes (1974), and oxygen can be measured before the pumping, in undisturbed groundwater. Temperature was measured in the stand pipe with the electrodes but it seems that more precise data are obtained when temperature of the interstitial water is measured with mercury thermometers after the water is pumped out.

The organic material was approximated only by taking into consideration the detritus fraction which remains in the plankton net after the washing operation. The detritus amount was carefully separated by elutriation and decantation and measured volumetrically using Schwoerbel's method (1961a).

The fauna was concentrated by the same method as the detritus and extracted under a low power stereo-microscope. Because I studied only samples fixed in formaldehyde, only the following groups were considered: rotifers, nematodes, oligochaetes, tardigrads, gastropods, bivalves, cyclopoids, harpacticoids, cladocera, isopods, amphipods, syncarids, ostracods, watermites, insect larvae. The pump method of collecting the interstitial animals and the elutriation-decantation method do not allow collection of the whole fauna of the sampled area (most probably), but provides a good insight into the relative abundance of the different animal groups.

For informations on the water quality degree (according to the Liebmann scale) of the Danube and the Piesting I used the data published in the maps "Biologisches Gütebild der Fließgewässer Niederösterreichs, Stand 1970/1971" and "Biologisches Gütebild der Fließgewässer von Wien und Umgebung, Stand 1972/1973" (1975) and the report published in 1975 by the Wasserwirtschaftskataster (Bundesministerium für Land- und Forstwirtschaft).

Some details on the most important sampling stations are given below:

1 - The Ebersdorf ("Melk") area (fig. 2,3): Large banks emerged in this area during the summer and autumn of 1973, 1974. The banks which are directly near the main water flow (fig. 2 the "a" area) have a very low permeability and porosity; the groundwater accumulates in low amounts in the holes dug one meter away from the river shore and it is impossible to obtain large amounts of groundwater with the Bou-Rouch pump (in this last case large amounts of sediment are sucked out). The compaction of the banks is very high and it is difficult to insert the pipe more than $0.50 \mathrm{~m}$ depth using a hammer of $10 \mathrm{~kg}$. The fauna sample was very poor. A second site (fig. 2 "b", $\mathrm{km} \mathrm{2041.1)} \mathrm{was} \mathrm{found} \mathrm{to} \mathrm{be} \mathrm{more} \mathrm{productive.} \mathrm{The} \mathrm{sediment} \mathrm{deposits} \mathrm{are} \mathrm{protected} \mathrm{by} \mathrm{a} \mathrm{dam} \mathrm{and}$ the river flow is attenuated (fig. 3). In this area, the groundwater accumulates quickly in the Karaman-Chappuis holes and by the pump method, large amounts of interstitial water as well as sediments were collected; these samples contained a rich fauna. From the results of pumping tests made on 7.10.1973, it is suggested that the sorting grade of the deposits is low, as high amounts of sediments (more than one liter) were sucked out (fig. 9F) both at $0.50 \mathrm{~m}$ and $1 \mathrm{~m}$ depth. It is possible that below $1 \mathrm{~m}$ depth or lateral to the stand pipe, the sorting grade of the sediments is better and a larger crevice system exists which enables the existance of a large number of isopods and cyclopoids (fig. 9B,C); in this area the water quality of the Danube has the degree 2 (from the Liebmann's scale).

2 - Tulln station: The bank is situated about $50 \mathrm{~m}$ downstream from the Tulln mouth. The water velocity of the river is high. The compaction of the sediments are not as high as in Melk. The Danube is periodically (in autumn and winter) polluted by the waste of the sugar plants existing 
along the Tulln stream. The water quality of the first river is generally considered to have a degree 2 .

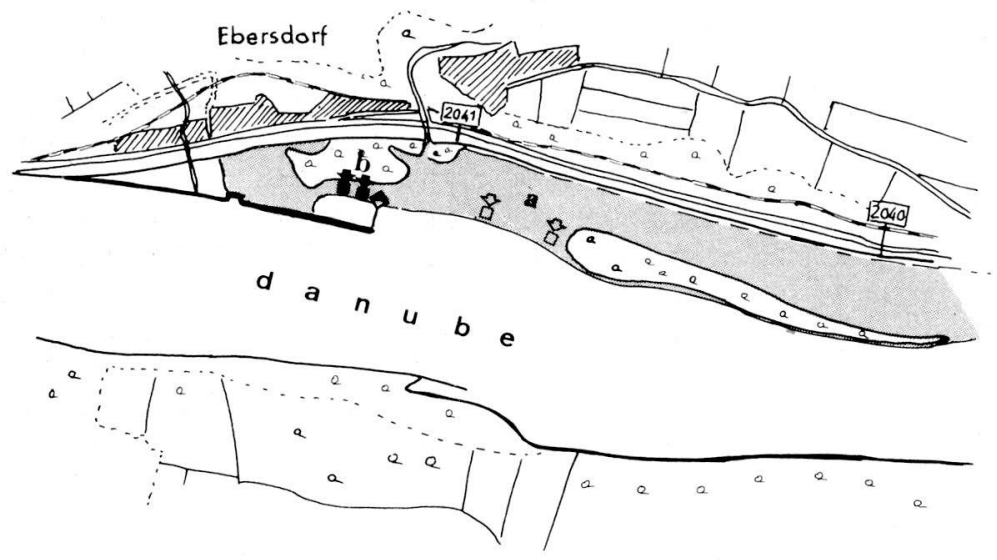

Fig. 2. The sampling site Ebersdorf (Melk); "a" and "b" stations where interstitial fauna was investigated.

3 - Wien-Floridsdorf: The beach has a high compaction and a low permeability. In both superficial and deeper layers the pump extracted large amounts of sediments with the water (fig. 9I). It was impossible to insert the stand pipe to more than $1.15 \mathrm{~m}$ depth. In this area the water of the Danube has the degree 2 as the first sewage channel from Vienna on the right side (Brünnerstraße Entlastungskanal) opens downstream near the Floridsdorf bridge. No signs of chemical reducing conditions were observed and moderate amount of detritus were found.

4 - Wien-Reichsbrücke: Sand and gravel are deposited near the shore in a small bay protected by a longitudinal dam (fig. 4A). Two places were investigated; the first one ("a") which is protected by the dam, had a richer fauna than that of the station " $b$ " which is more influenced by the water of the Danube. From both sampling stations, high amounts of sediment and black coloured water were collected. In the deeper layers of sediment, high amounts of detritus and chemical reducing conditions were found (water smelling of $\mathrm{H}_{2} \mathrm{~S}$ ). In the area of Reichsbrücke the water quality of the Danube has a degree of 2-3.

5 - Fischamend: The compaction of the sediments is less than that of the sediments in Melk, Tulln and Vienna. The water quality has the degree 4 as the station is located downstream to the strongly polluted Schwechat stream and to Vienna.

6 - Wildungsmauer: The station is located in a dead arm of the Danube at about $100 \mathrm{~m}$ from the river. The gravel bank emerges during low water. The compaction is very low. No signs of pollution were observed.

7 - March: The bank is located upstream (about $50 \mathrm{~m}$ ) from the March mouth. The sediment bank formed mostly from gravel and sand is protected from the water flow of the Danube river by a longitudinal dam. Sediment compaction is very low. This is the only place where the stand pipe 
INTERSTITIAL FAUNA OF DANUBE AND PIESTING
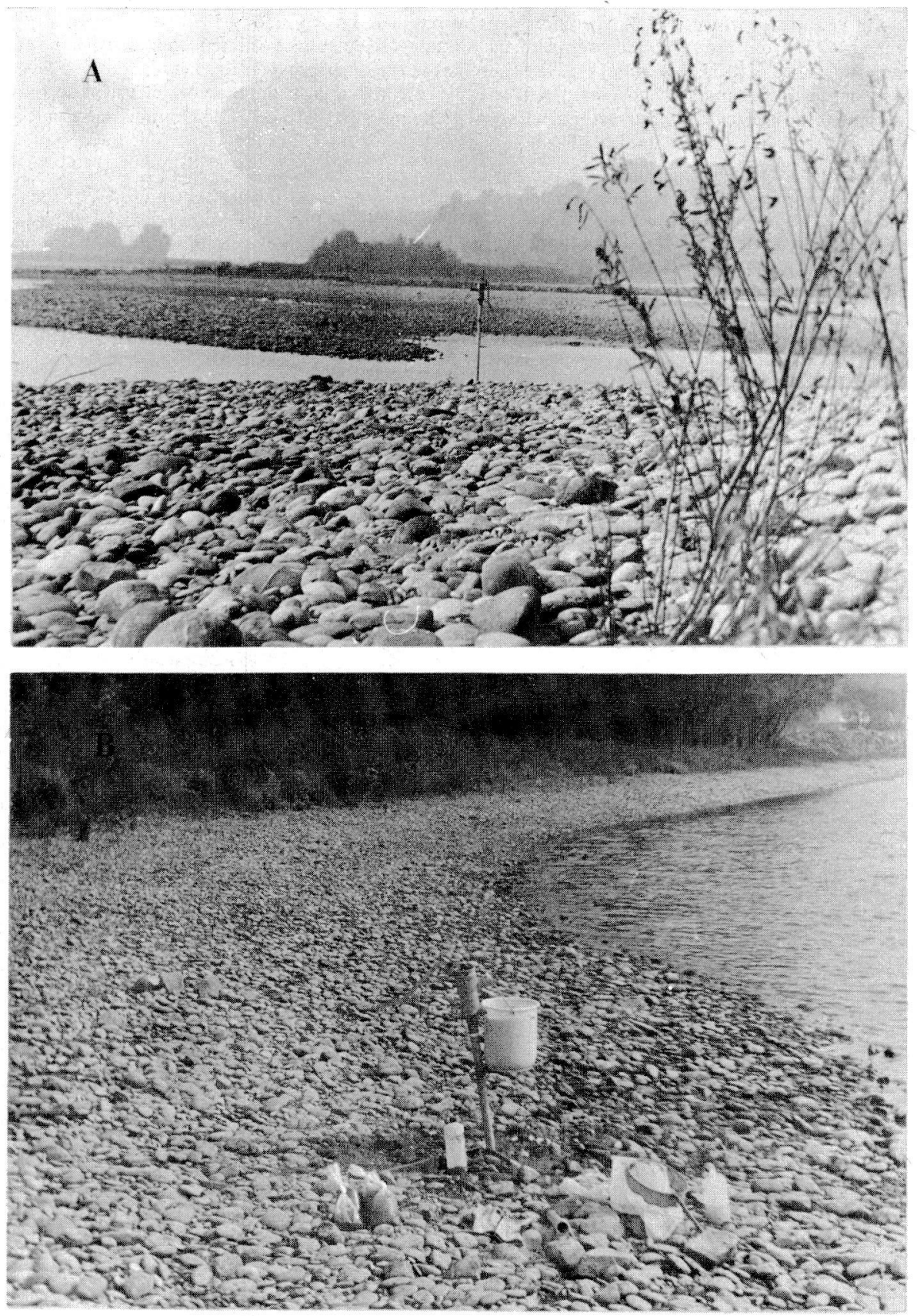

Fig. 3. The sampling site Ebersdorf (Melk); A — view of area "a"; B — view of area "b". 
could be inserted down to $3 \mathrm{~m}$. Groundwater was pumped out (fig. 4B) in 1973 from the area "a" and in 1974 from area " $b$ ". According to the amount of sediment extracted, the porosity in the superficial layers $(0.75$ to $1.50 \mathrm{~m})$ is lower than that in the deeper layers (fig. 13) for point "b". At $3 \mathrm{~m}$ depth in the point "a", occurs a reduced horizon with a large amount of detritus, and fine sediments with black coloured water smelling of $\mathrm{H}_{2} \mathrm{~S}$ and with oil traces. The Danube water in the "March" area has a water quality of 2-3.

8 - Piesting: The station is located upstream from Moosbrunn near the groundwater plant Moosbrunn II, which will supply Vienna with drinking water. The Piesting stream in this area has a water quality of degree 3. Large amount of Sphaerotilus natans and high numbers of the amphipod Gammarus roeseli were found. The Coli and coliform bacteria have concentrations of more than 100000 cells $/ 100 \mathrm{ml}$. The stand pipe was introduced directly under the streambed at 0.50 $0.70 \mathrm{~m}$ depth. Between 1000 and $1500 \mathrm{ml}$ sediment were extracted. No signs of reducing chemical conditions were observed. In this paper the fauna inhabiting only the subterranean waters will be

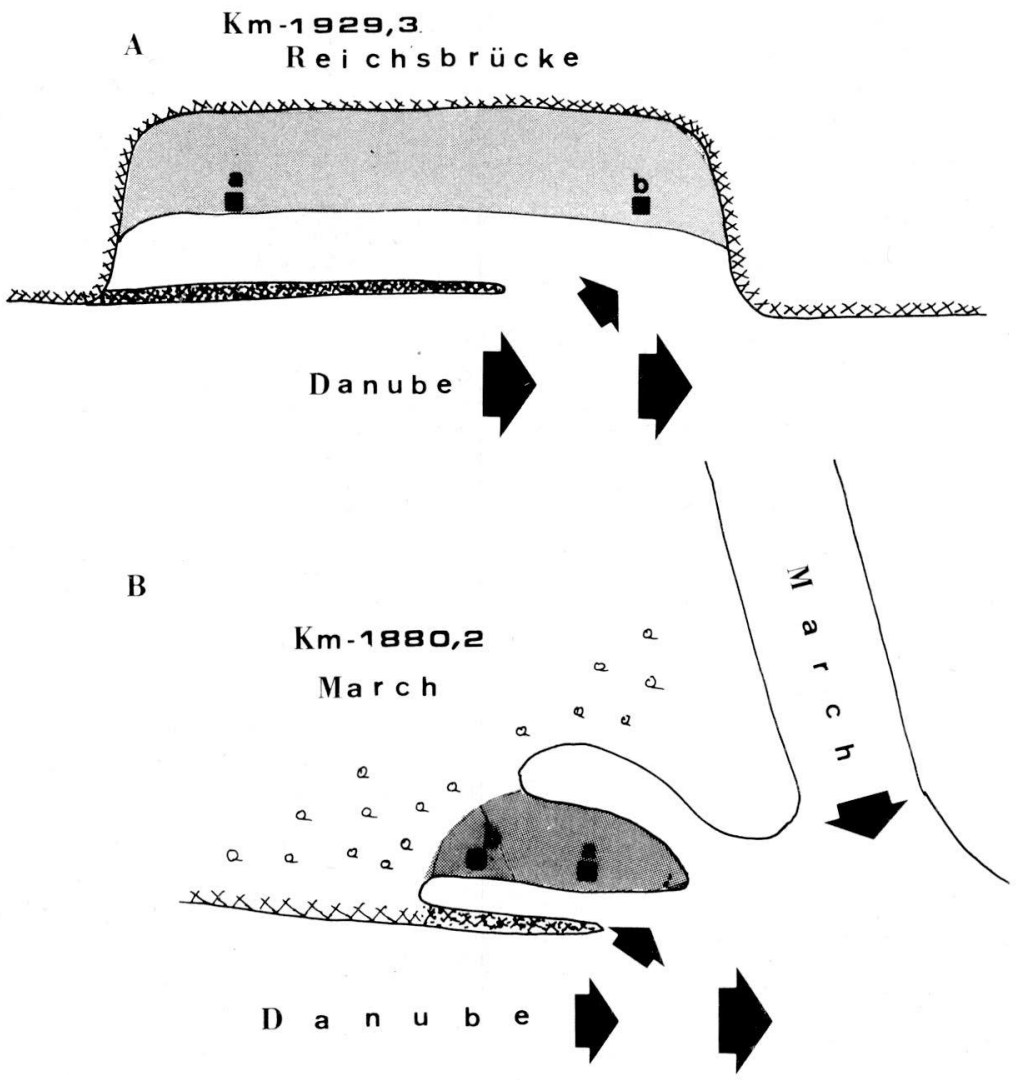

Fig. 4. The sampling sites A - Wien-2 (Reichsbrücke) and B - March; "a" and "b" stations where interstitial fauna was investigated (Schematic representation). 
termed "hypogean fauna" (the animals are troglobites sensu-lato). The interstitial fauna which can be encountered in surface water, too, is termed "epigean fauna" (the animals are troglophiles and trogloxenes).

\section{GENERAL DISTRIBUTION OF THE MAIN FAUNAL GROUPS}

The following animal groups were investigated: Rotatoria, Tardigrada, Gastropoda, Oligochaeta, Nematoda, Cyclopoida, Harpacticoida, Cladocera, Ostracoda, Isopoda, Amphipoda, Insect larvae (mainly Chironomidae), Hydracarina. The nematodes, the oligochaetes and the cyclopoids are the most

Table 3. The abundance of the different animal groups in the 1 st, 7 th and 12 th " 10 liter" samples at $\mathrm{km}$ 2041.1 Ebersdorf (Melk); 7.10.1973; depth $1 \mathrm{~m}$; $\mathrm{n}$ - number of animals.

$$
\text { Km-2041,1 (MELK) 7.10.1973 h-1m }
$$

\begin{tabular}{|l|c|c|c|c|c|c|}
\hline & \multicolumn{2}{|c|}{ I } & \multicolumn{2}{c|}{ VII } & \multicolumn{2}{c|}{$\times 11$} \\
\cline { 2 - 7 } & $n$ & $\%$ & $n$ & $\%$ & $n$ & $\%$ \\
\hline AMPHIPODA & 0 & 0 & 1 & 0,17 & 2 & 0,34 \\
ISOPODA & 1 & 1,20 & 95 & 16,78 & 194 & 33,44 \\
CYCLOPOIDA & 6 & 7,22 & 394 & 69,61 & 345 & 59,48 \\
HARPACTICODA & 0 & 0 & 0 & 0 & 0 & 0 \\
OST RACODA & 1 & 1,20 & 14 & 2,47 & 18 & 3,10 \\
CLADOCERA & 1 & 1,20 & 10 & 1,76 & 2 & 0,34 \\
NEMA TODA & 67 & 80,72 & 36 & 6,36 & 9 & 1,55 \\
OLIGOCHETA & 7 & 8,43 & 12 & 2,12 & 9 & 1,55 \\
INS. LARVAE & 0 & 0 & 4 & 0,70 & 1 & 0,17 \\
HYDRACHARINA & 0 & 0 & 0 & 0 & 0 & 0 \\
\hline T OTAL $\mathrm{n}$ & 83 & & 566 & & 580 & \\
\hline
\end{tabular}


Table 4. The abundance of the different animal groups in the 1st " 10 liter" samples at km 1932.2 Wien 1 (Floridsdorf); 27. and 29.09.73; depth 0.50 and $1 \mathrm{~m}$ )

Km-1932,2WIEN Floridsdorf) 27 - 29.09.1973

\begin{tabular}{|c|c|c|c|c|c|c|c|}
\hline Pr. I & NEMAT & OLIGO & HARPACT & PARASIE & CYCLO & OSTR A & HYDRA \\
\hline $50 \mathrm{~cm}$ & 515 & 170 & 3 & 0 & 0 & 0 & 0 \\
\hline 27.09 & 74,85 & 24,70 & 0,43 & 0 & 0 & 0 & 0 \\
\hline $100 \mathrm{~cm}$ & 531 & 118 & 0 & 25 & 21 & 40 & 11. \\
\hline $29.09 \%$ & 71,17 & 15,81 & 0 & 3,35 & 2,81 & 5,36 & 1,47 \\
\hline
\end{tabular}

$\mathrm{n}$ - number of animals in each group; $\mathrm{nt}$ - total number of animals in sample; $\% \mathrm{nt}$ - the different animal groups as \% of the total number of animals found in each sample.

abundant groups (fig. 8, 9, A-E and tables 3,4). In some of the samples, the nematodes are the dominant group. This is the case in samples from Melk (fig. 8G, H, 9A and table 3(I)), Wien-Floridsdorf (fig. 9D, E, table 4), Fischamend (fig. $8 \mathrm{~K}, \mathrm{~L}$ ), where they represent between 60 and $80 \%$ of the total number, and in some samples from March (fig. 8A, D-F), where they represent between 50 and $67 \%$. In samples in which the nematodes are numerically less important, the cyclopoids are dominant, for instance from Melk (fig. 9B, C, table 3 (VII, XII)), from Tulln (fig. 8I, J), where they represent between 55 and $75 \%$, and some samples from March (fig. 8B, C), where they represent about 40-45\%. The highest numbers of nematodes were observed in samples containing large amounts of sediment, for instance in Melk at $0.50 \mathrm{~m}$ depth (fig. 8E), Wien-Floridsdorf (fig. 9D, E, I), Fischamend (fig. 8K, L). This does not seem to be a general rule, however, because in March (fig. 13) 11.10.1974, despite the fact that there are obvious differences in the sediment at the 0.75 and 1.50 $\mathrm{m}$ samples, the quantitative differences of the nematodes are not so important. In Melk, on 7.10.1973, the amount of sediment in the 0.50 and $1 \mathrm{~m}$ samples are rather similar (about $1300 \mathrm{ml}$ ) but there are large differences in the number of nematodes (1032 against 67 specimen).

It is interesting to notice that in the deeper layers $(1 \mathrm{~m})$ in Wien-Floridsdorf, the nematode association (represented by 7 species) is dominated (more than $80 \%$ ) by a hypogean species belonging to the genus Theristus (Dr. Schiemer and Cand. phil. Eder, det.). This last species represents only $60 \%$ in the upper 

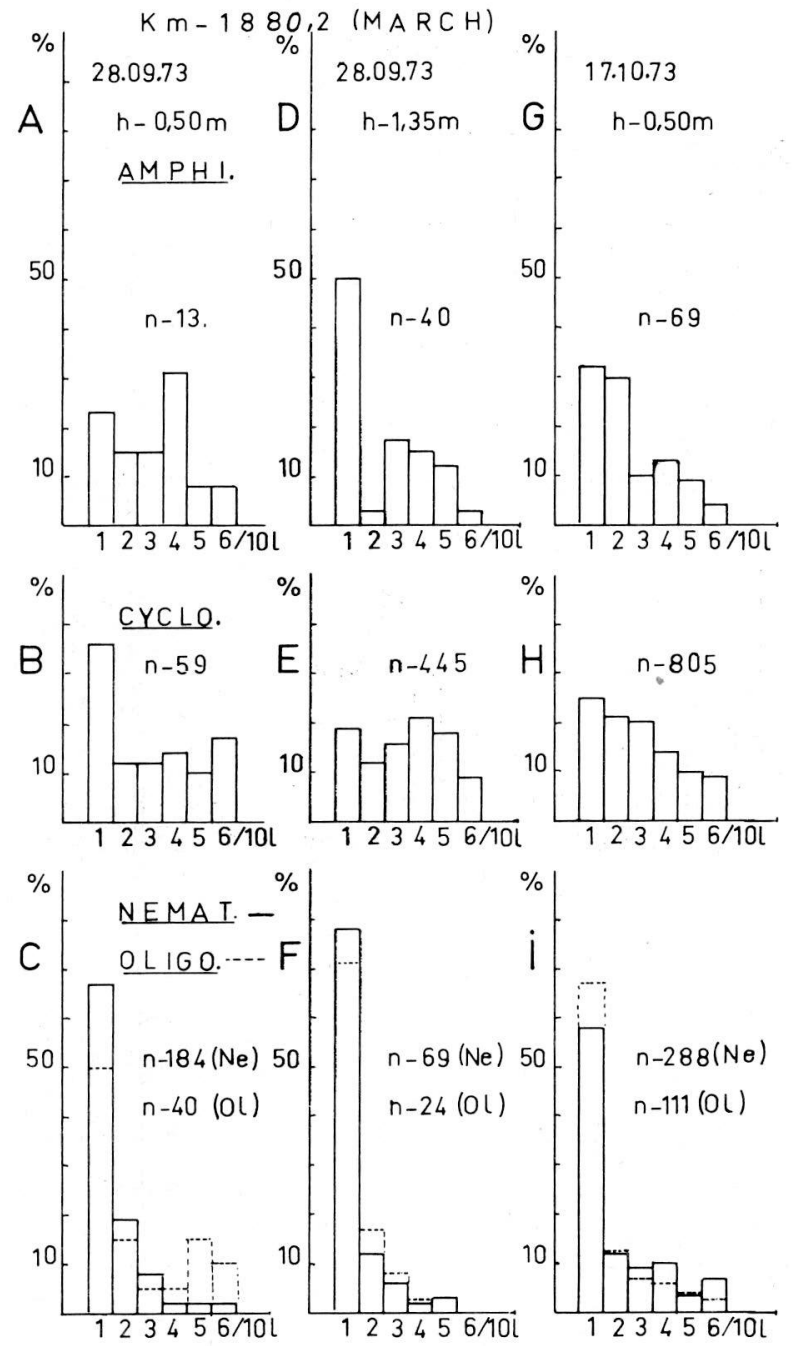

Fig. 5. The abundance of several animal groups as a percent (calculated from the total number of animals of each group found in 60 liters) in 6 successive samples of 10 liters (water and sediment); A, D, G - Amphipoda; B, E, H - Cyclopoida; C, F, I - Nematoda and Oligochaeta; A, C and G-I - depth $0.50 \mathrm{~m} ; \mathrm{D}, \mathrm{F}$ - depth $1.35 \mathrm{~m}$. 
$\mathrm{Km}-1880,2$ (MARCH)

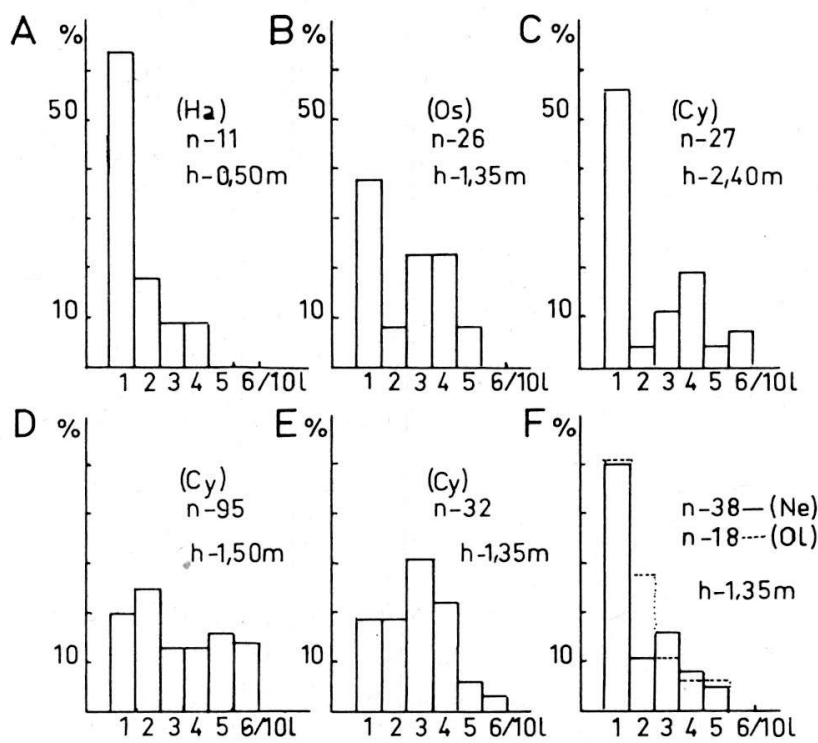

$$
\begin{array}{ll}
A-D-28.09 .73 & G-30.08 .73 \\
E-F-17.10 .73 & H-5.08 .73 \& 2.09 .73
\end{array}
$$

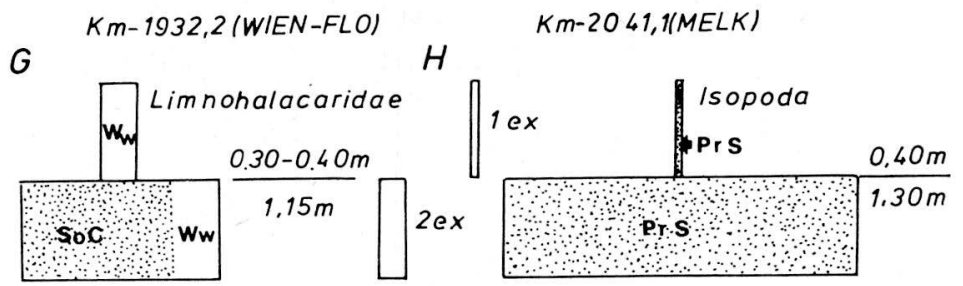

Fig. 6. The abundance of several animal groups calculated as the number of animals of each group found in 60 liters in 6 successive samples ( $\mathrm{Ww}$ - Walterella weberi, SoC - Soldanellonyx chappuisi, $\mathrm{PrS}$ - Proasellus slavus, ex - specimen). 


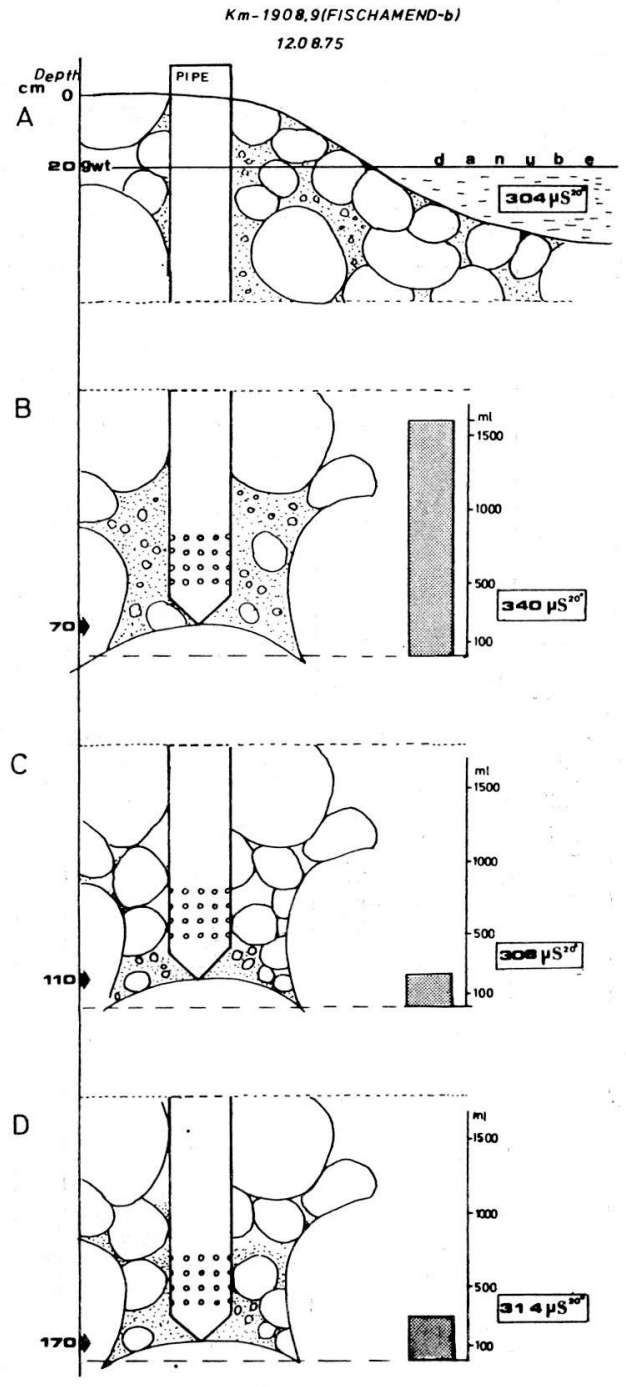

Fig. 7. Diagrammatic representation of the interstitial system of the riverine sediments at the station "Fischamend"; $\square$ the amount of sediment sucked with the pump in the 1 st 10 liters at different depths; $\mu \mathrm{S}^{20}$ - electric conductivity of water expressed in microsiemens at $20^{\circ} \mathrm{C}$ (det. R. Eder). 


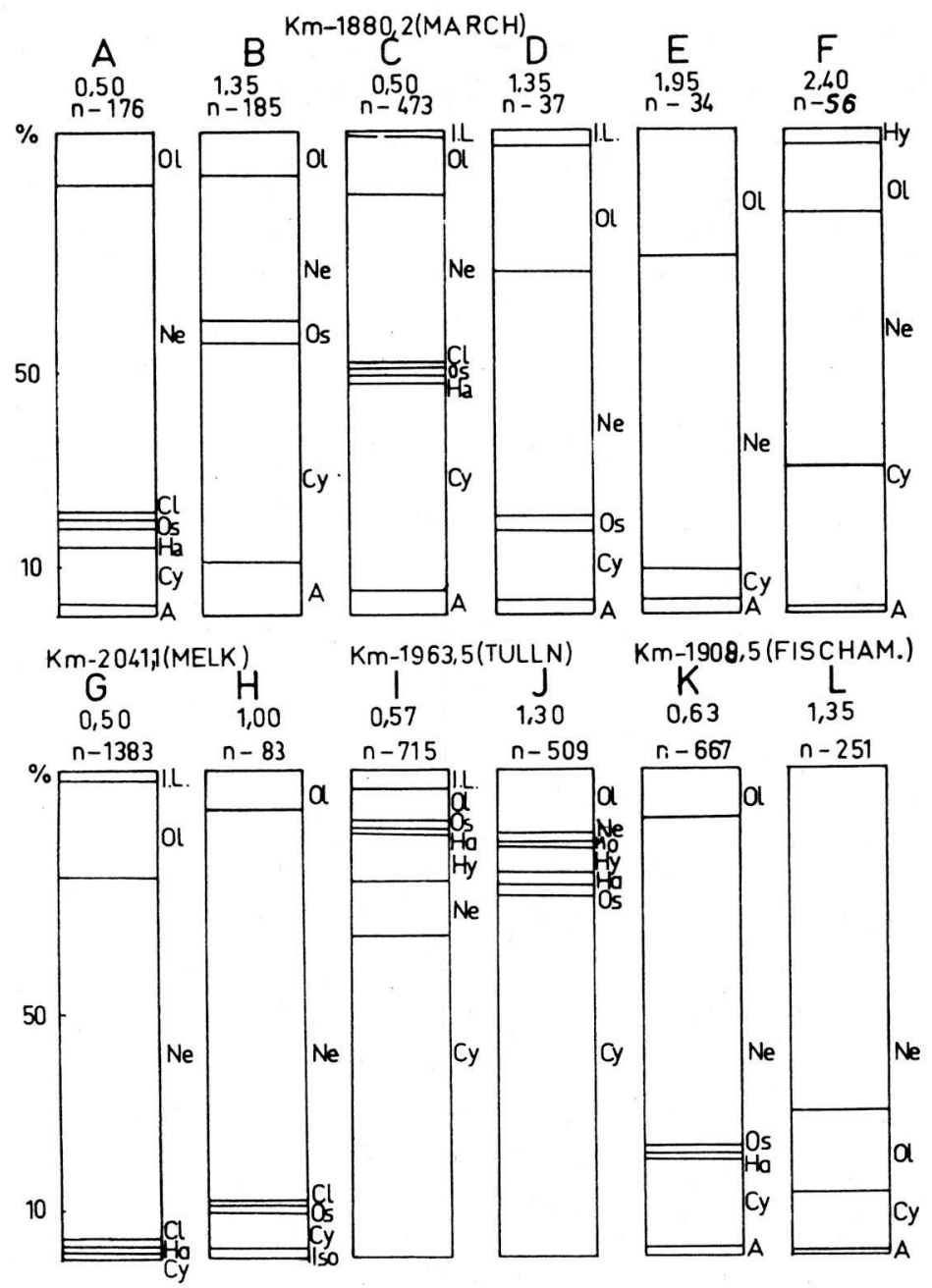

Fig. 8. The abundance of different animal groups in the 1 st 10 liters sample from various localities and from different depths; A-F - km 1880.2 (March), A, B, F - 20.09.1973; C, D, E - 17.10.1973; G, H - km 2041.1 (Melk), 7.10.1973; I, J - km 1963.5 (Tulln), 25.09.1973; $\mathrm{K}, \mathrm{L}-\mathrm{km} 1908.5$ (Fischamend), 29.10.1973. 


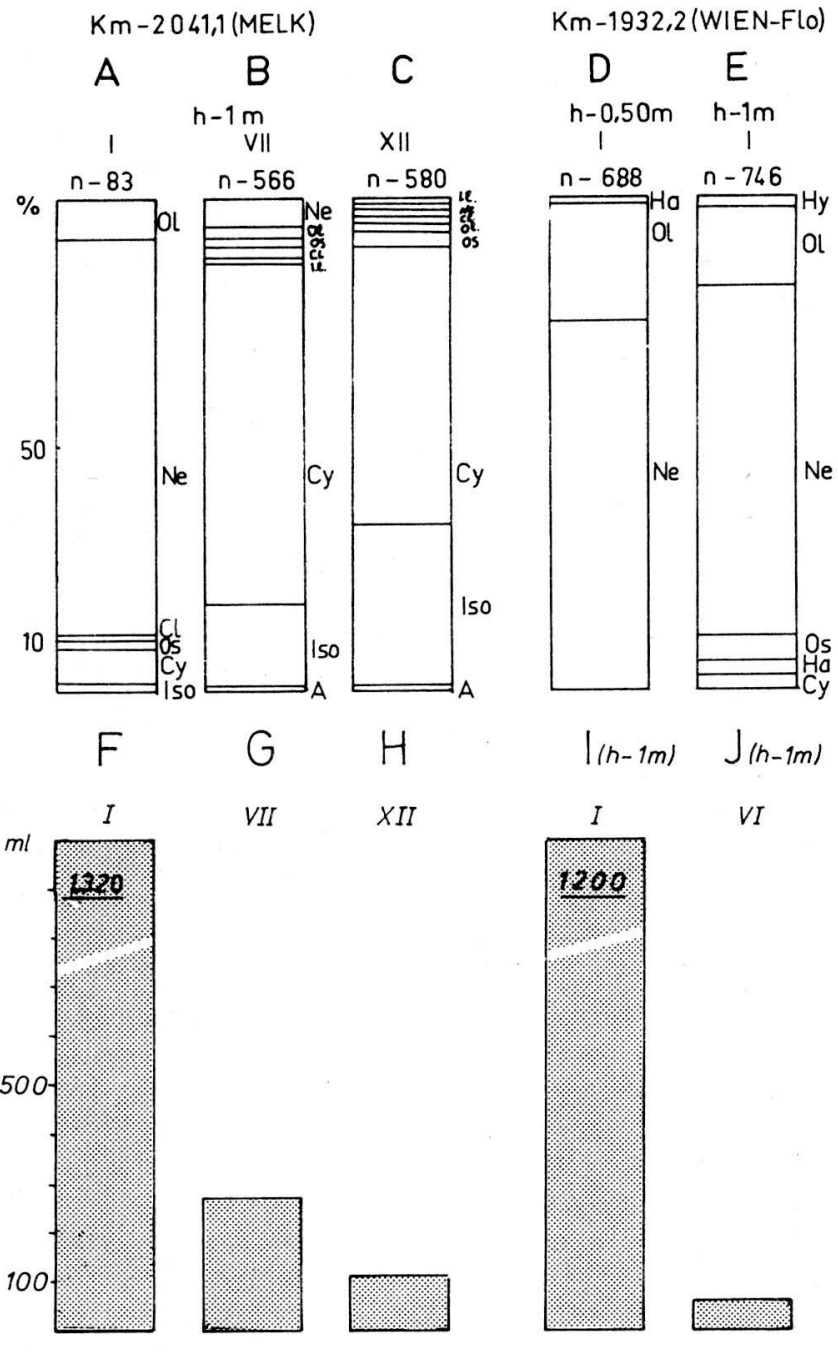

Fig. 9. The abundance of the animal groups (as a percentage of the total fauna of a 10 liters sample) (A-E) and the amount of sediment (F-J) found in several samples from Melk (A-C, F-H) and Floridsdorf at $1 \mathrm{~m}$ depth (exception D $-0.50 \mathrm{~m}$ depth); roman numbers represent the various 10 liters samples. 

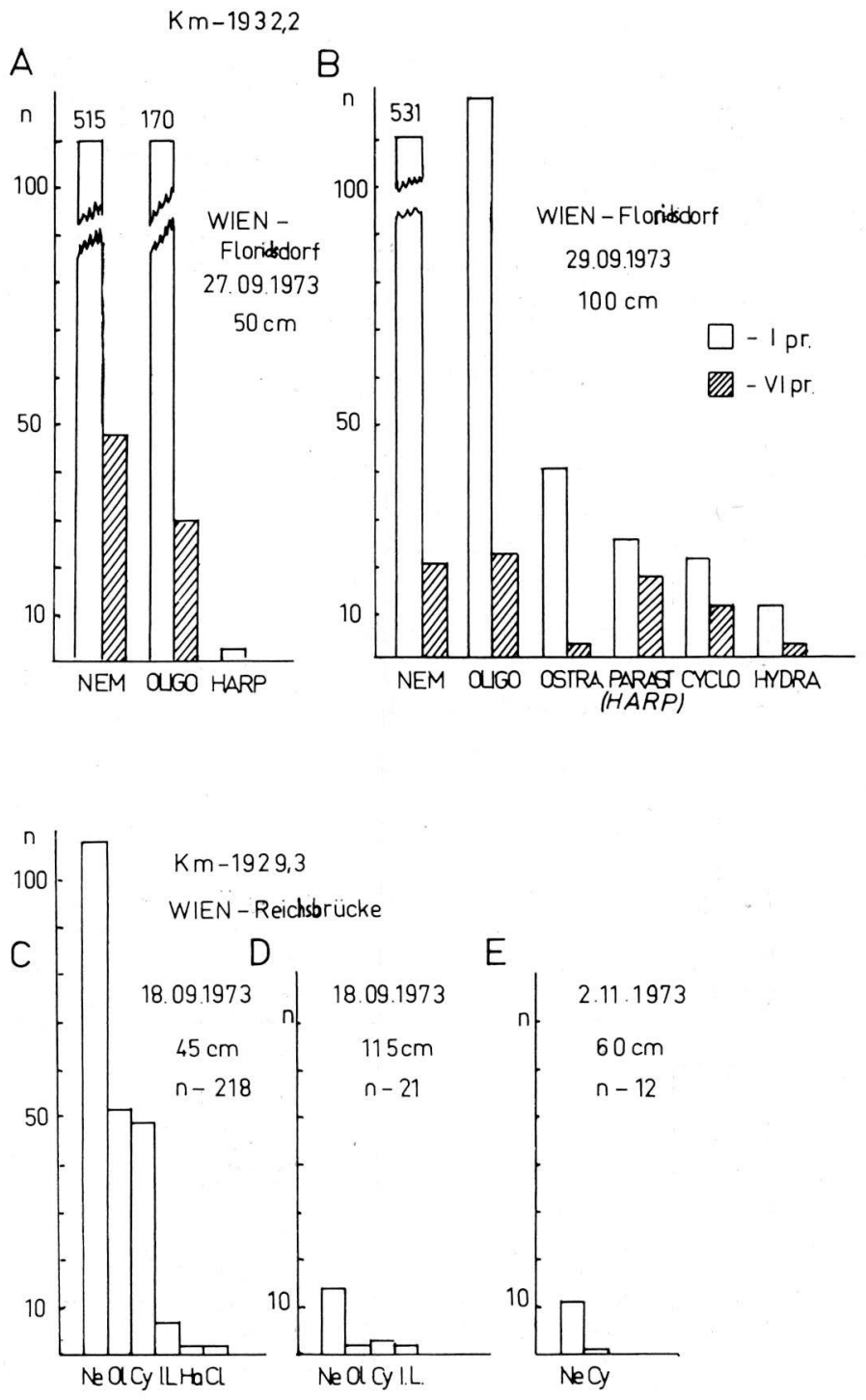

Fig. 10. The abundance of various animal groups in samples from the two Viennese sample stations; $\square$ ist 10 liters sample; 10 liters sample; Parast - Parastenocaris sp. 


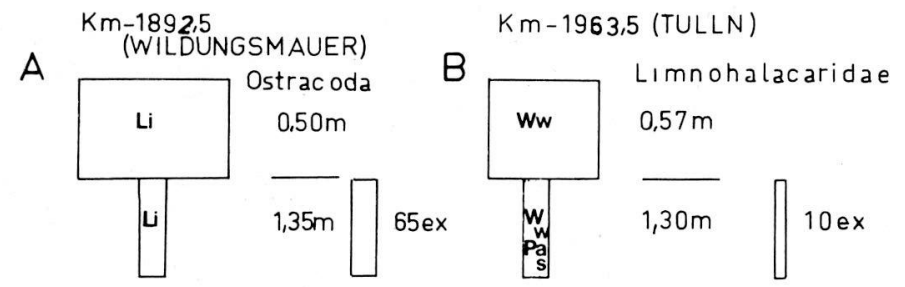

Km-1932,2 (WIEN-FLO)

$\mathrm{Km}-1880,2$ (MARCH)

C
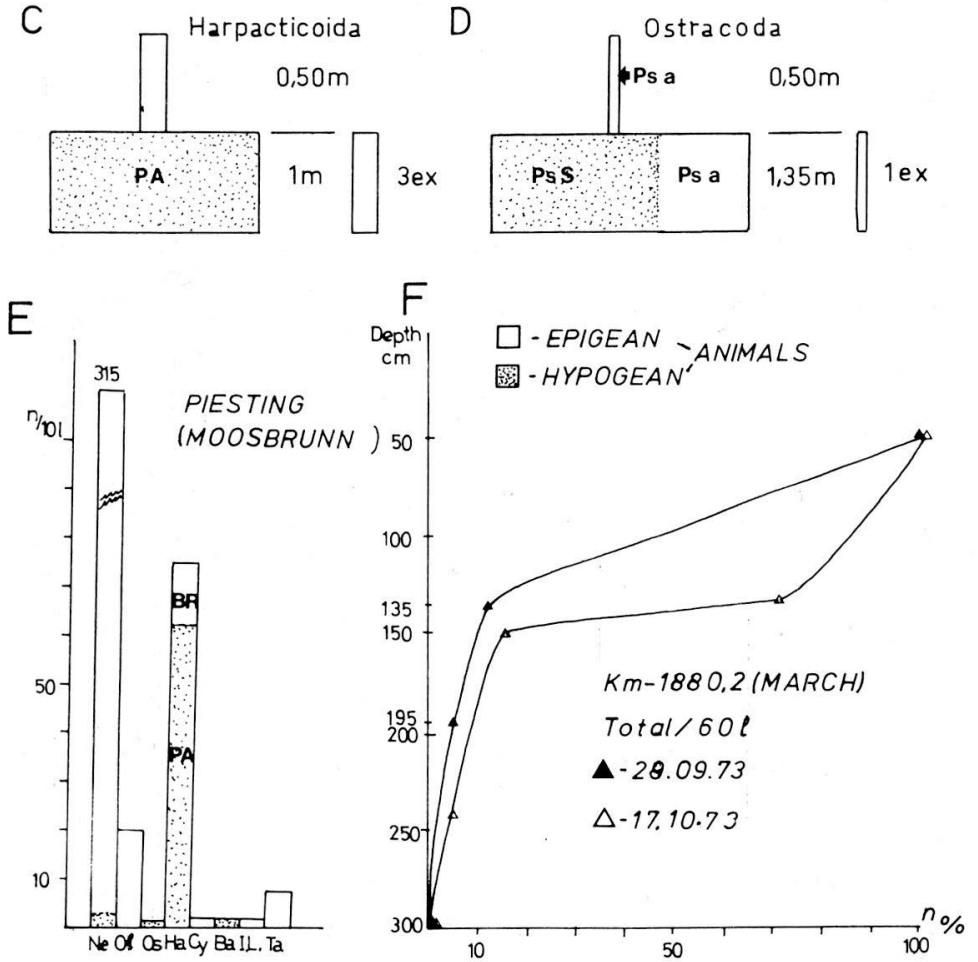

Fig. 11. A-D - The quantitative distribution of some animal groups in the 1 st 10 liter samples at different depths; $\mathrm{E}$ - the abundance of different animal groups in the 1st 10 liter sample at $0.70 \mathrm{~m}$ depth from Piesting at Moosbrunn (under the stream bed at 20.02.1975; $\mathrm{F}$ - the quantitative distribution of the fauna in 60 liters sample from March station at different depths represented as percent on cumulative curves ( $\mathrm{Li}$ - Limnocythere inopinata, PsS - Pseudocandona aff. szösci, Psa - Pseudocandona albicans, PA Parastenocaris sp., BA - Bryocamptus sp., Ww - Walterella weberi, Pa $\mathrm{s}$ Parasoldanellonyx parviscutatus, ex - specimen). 

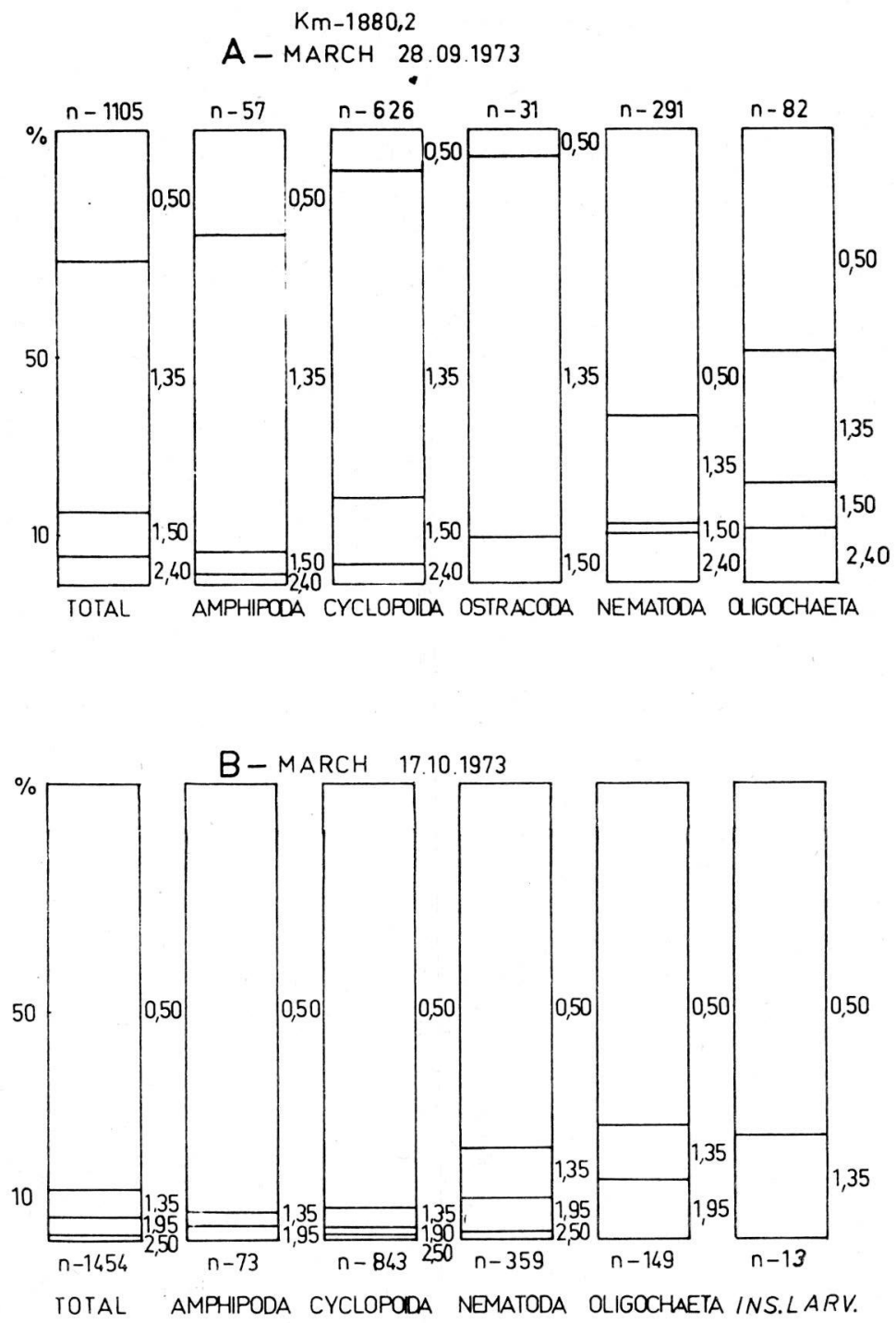

Fig. 12. The quantitative distribution of the animal groups in the 1 st 10 liter samples at different depths (as percentages of the total number of each group) at "March" station (A 28.09. 1973; B - 17.10.1973). 


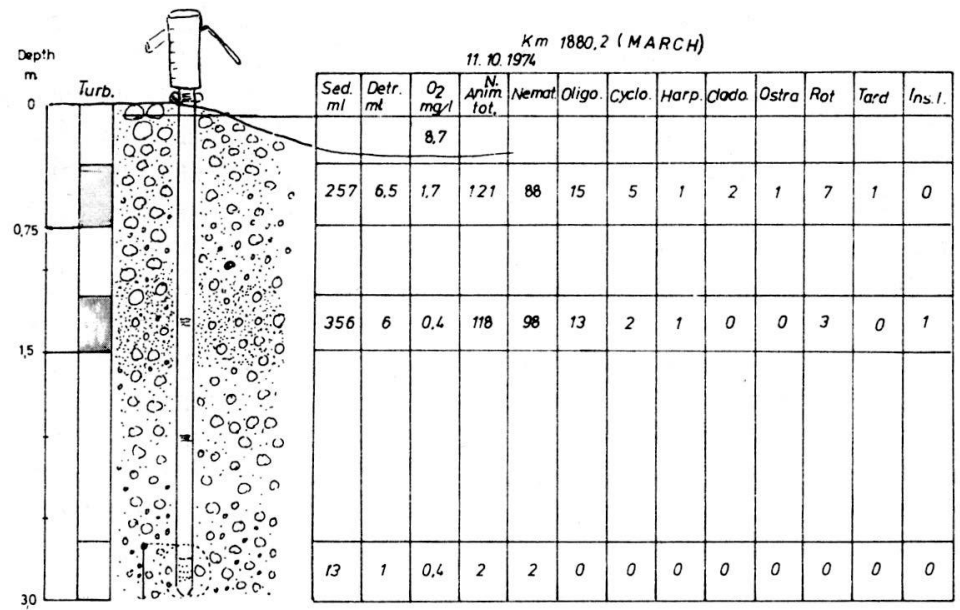

Fig. 13. The quantitative distribution of the animal groups in the 1 st 10 liter samples at different depths at "March" station (11.10.1974); the amount of sediment, detritus, the oxygen concentration, the intensity of the water turbidity (turb) and the diagrammatic representation of the interstitial system at different depths where water and sediment were pumped out.

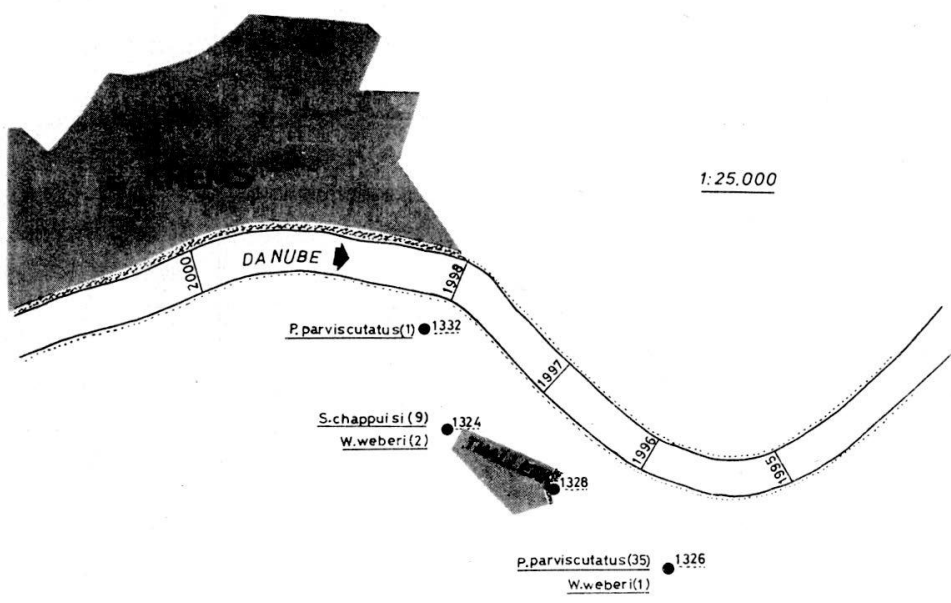

Fig. 14. The distribution of different limnohalacarids in wells (black dots) in the Krems-Thallern area the number of individuals are found in brackets. 
layer. In the Piesting sample at $0.50-0.70 \mathrm{~m}$ depth a remarkable hypogean species, Stenonchulus troglodytes was found (Eder, 1975). The most important number of cyclopoids occurs in samples with low amounts of sediment [for instance in Melk samples VII and XII at 7.10.1973 (table 3 and fig. 9B, C)]. The insect larvae and harpacticoids are very poorly represented (fig. 8, 9, 10, 13 and tables 3 and 4). The insect larvae are represented mostly in the superficial layers from Melk, Tulln, Wien-Reichsbrücke and March. In the samples from deeper layers, the insect larvae are less abundant or they are lacking (fig. $10 \mathrm{C}, \mathrm{D})$. The harpacticoids do not represent more than $3.5 \%$, except in the samples from Wien-Floridsdorf (1 m depth) (table 4) and Moosbrunn-Piesting (0.50-0.70 $\mathrm{m}$ depth) (fig. 11E). In these latter cases the harpacticoid fauna (det. Prof. Löffler) is dominated by a hypogean species of the genus Parastenocaris*. The harpacticoids from the upper layers of Wien-Floridsdorf and March are epigean species. In the last station at $0.50 \mathrm{~m}$ Campthocamptus staphylinus occurs (det. Dr. Neuhuber).

The cladocera, rotifers, gastropods, tardigrads are insignificant groups in all the samples. They make up less than $3 \%$ and occur mainly in the upper interstitial layers (fig. 8, 9, 11E, 13, table 3). The isopods are represented by the hypogean species Proasellus slavus (Dr. Sket det.). This species occurs mainly in deep layers at Melk. The highest numbers are registered in samples with little sediment (fig. 9, VII, XII. In this last sample they represent $17 \%$ of the total fauna). Few specimens of $P$. slavus were found in a sample from March (table 5 ). The amphipods are represented only by hypogean species (blind and unpigmented); they have been found in March, Fischamend and Melk. The highest numbers occur in several samples from March (fig. 5A, D, G and 8B, C) in upper layers $(0.50 \mathrm{~m})$ as well as in deeper layers $(1.35$ and $1.95 \mathrm{~m})$. They usually represent less than $10 \%$ of the total fauna, an exception being a sample from $1.35 \mathrm{~m}$ (fig. 8B).

The ostracods generally make up less than $10 \%$ of the total fauna (fig. 8, 9, $10,11 \mathrm{E}$ ). Most of the specimens belong to hypogean species (Kovalevskiella sp., Mixtacandona laisi vindobonensis, M. aff. transleithanica, Cryptocandona kieferi, Pseudocandona aff. szösci, Fabaeformiscandona wegelini). In the deeper layers from Wien-Floridsdorf (table 4) Kovalevskiella sp. occurs, $F$. wegelini and $M$. laisi vindobonensis occur in Melk, C. kieferi in Tulln and $P$. aff. szösci (fig. 11D) is mostly present in deeper layers $(1.35 \mathrm{~m})$ from March. In the samples from Wildungsmauer the ostracod fauna is represented by an epigean species, Limnocythere inopinata (fig. 11A). In March an epigean ostracod, Pseudocandona albicans (fig. 11D) was found more abundant in the upper layers.

The Hydracarina are represented only by limnohalacarids (epigean and hy-

*) In the Samples from Piesting, a specimen of Nitocrella sp. has also been found and the epigean harpacticoids are represented by 5 Bryocamptus species: B.typhlops, B.zschokkei, B.weberi B.echinatus, B.pygmaeus. 
pogean species). They are common both in the surface (up to $10 \%$ ), and in the deeper layers (up to 5\%) in Tulln (fig. 8I, J, 11A). In Wien-Floridsdorf they occur only in the deeper layers (fig. 9E and table 4). They are present in low numbers in a sample from March in $2.40 \mathrm{~m}$ depth (fig. $8 \mathrm{~F}$ ). The following species were found (det. Prof. Schwoerbel): Walterella weberi (epigean species)* in Melk, Tulln (112 specimen!), Wien-Floridsdorf, Wildungsmauer and March, Parasoldanellonyx parviscutatus (epigean species) in Tulln, Soldanellonyx chappuisi (hypogean species according to Schwoerbel, personal communication) in Wien-Floridsdorf (fig. 6G). W. weberi is more abundant in the superficial layers (fig. 11B) from Tulln. S. chappuisi (fig. 6G) and P. parviscutatus (fig. 11B) have been found in the deeper layers of the riverine banks investigated.

If one compares the faunistic data presented above with that presented by Schwoerbel (1961a) for the Breg (fauna collected in Karaman-Chappuis holes dug to maximum $50 \mathrm{~cm}$ depth) several features are obvious:

1) The most abundant groups are not the insect larvae and harpacticoids (as is the case of the Breg, where the latter group could represent more than $50 \%$ of the total fauna in some samples and the insect larvae about $30 \%$ ) but the nematodes, oligochaetes and cyclopoids.

2) The absence of hydrachnellids, many species of which were found in the hyporheal of the Upper Danube area investigated by Schwoerbel (1961b and 1964a), is another striking feature. Several explanations can be offerred for these differences: 1) The compaction and the low effective porosity of some sediments could limit the population of the interstitial system in some cases. This may be the case in the riverine sediments occurring in Melk, Wien-Floridsdorf and Reichsbrücke, in the upper layers of Fischamend and on Piesting at Moosbrunn, but this is certainly not the situation in March, Wildungsmauer and, to a lesser extent, in Tulln. 2) The hydrachnellids, the harpacticoids and the insect larvae are less well represented than the nematodes and cyclopoids in the Danube river (area investigated). Comparing the biomass of oligochaetes and chironomids in several samples collected in the Danube at Bratislava, Ertlova (1968) found that the former group is more abundant than the latter. In samples from the Danube at Melk, Wien, Fischamend and March insect larvae and harpacticoids occur, but I could not find any hydrachnellids. In the Upper Danube, Schwoerbel (1964a) found a rich fauna occurring in unpolluted areas.

The comparative lack of hydrachnellids and the scarcity of insect larvae in the austrian area investigated are not due to the sampling method (Bou-Rouch pump). Similar results were obtained even when the Karaman-Chappuis method was used (see table 1) in the way of Schwoerbel.

Ruffo (1961) also found few insect larvae and the lack of hydrachnellids in the riverine sediments of Adige near Verona (a middle altitude area).

*) Walterella $=$ Porohalacarus. 


\section{REMARKS ON THE INTERSTITIAL FAUNA IN TERMS OF VERTICAL DISTRIBUTION}

In the March area where samples were collected in 1973 down to 3 metres (station "a"), the highest densities occur in the upper $1.50 \mathrm{~m}$ (see fig. $11 \mathrm{~F}, 12$ and table 5). This is also the case of the samples from 1974 (fig. 13). In this latter case, oxygen concentration, organic material and sediment were also measured. There is a large difference in the faunal distribution and the amount of sediment and detritus (fig. 13), between samples from upper layers $(0.75$ and $1.50 \mathrm{~m}$ ) and those from the deeper one $(3 \mathrm{~m})$. The maximum abundance of the fauna in the upper layers is most probably due to a complex of factors in

Table 5. The abundance (number of animals) of the different animal groups in 60 liters, from various depths in the "March" bank.

\begin{tabular}{|c|c|c|c|c|c|c|c|c|c|c|}
\hline \multicolumn{4}{|c|}{$\mathrm{Km} 1882,2$} & \multicolumn{2}{|c|}{28.09 .1973} & \multicolumn{5}{|c|}{1601} \\
\hline & A & 120 & Cy & $\mathrm{Ha}$ & Os & $\mathrm{Cl}$ & $\mathrm{Ne}$ & Ol & I.L. & $\mathrm{Hy}$ \\
\hline $0,50 \mathrm{~m}$ & 13 & 0 & 59 & 11 & 2 & 1 & 184 & 40 & 1 & 0 \\
\hline $1,35 \mathrm{~m}$ & 40 & 2 & 445 & 0 & 26 & 0 & 69 & 24 & 0 & 0 \\
\hline $1,50 \mathrm{~m}$ & 3 & 0 & 95 & 0 & 3 & 0 & 6 & 8 & 1 & 0 \\
\hline $2,40 \mathrm{~m}$ & 1 & 0 & 27 & 0 & 0 & 0 & 32 & 10 & 0 & 2 \\
\hline Total & 57 & 2 & 626 & 11 & 31 & 1 & 291 & 82 & 2 & 2 \\
\hline \multicolumn{11}{|c|}{ 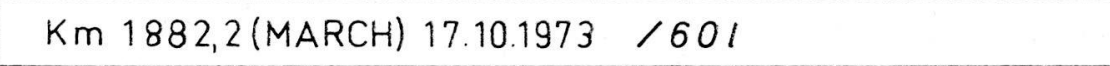 } \\
\hline $0.50 \mathrm{~m}$ & 69 & 0 & 805 & 8 & 3 & 4 & 288 & 111 & 10 & 0 \\
\hline $1,35 \mathrm{~m}$ & 2 & 0 & 32 & 0 & 3 & 0 & 38 & 18 & 3 & 0 \\
\hline $1.95 \mathrm{~m}$ & 2 & 0 & 4 & 0 & 0 & 0 & 26 & 20 & 0 & 0 \\
\hline $2.50 \mathrm{~m}$ & 0 & 0 & 2 & 0 & 0 & 1 & 7 & 0 & 0 & 0 \\
\hline Total & 73 & 0 & 843 & 8 & 6 & 5 & 359 & 149 & 13 & 0 \\
\hline
\end{tabular}

List of abbreviation for the different animal groups: A - Amphipoda; Iso - Isopoda; Cy - Cyclopoida; $\mathrm{Ha}$ - Harpactoida; Os - Ostracoda; $\mathrm{Cl}$ - Cladocera; Ne - Nematoda; IL - Insect larvae; Ro - Rotifera; Hy - Hydracarina. 
which food supply, effective porosity and oxygen concentration together play an important role. The low value of the oxygen concentration of the interstitial water alone do not seem to be a restrictive factor, a rich fauna occurs at the $1.50 \mathrm{~m}$ depth of March (fig. 13) but not at $3 \mathrm{~m}$ (both of which have the same $\mathrm{O}_{2}$ concentration of $0.4 \mathrm{mg} / \mathrm{l}$ ). Only strong chemical reducing processes occurring in deeper layers, as in Wien-Reichsbrücke (point $\mathrm{b}, 1 \mathrm{~m}$ depth), and March at $3 \mathrm{~m}$, in the station "a" (samples from 1973), can completely eliminate the interstitial fauna.

The investigations of Schwoerbel (1961a), Husmann (1966), Rouch (1971), Lecher-Moutoué (1974) and Williams and Hynes (1974) showed that the epigean fauna decreases in quantity and in some cases the hypogean fauna increases both qualitatively and quantitatively with the depth of the interstitial sediments. Such patterns were also found for some groups in the area investigated (fig. 6G, H and 11 A-D for the limnohalacarids, isopods*, ostracods and harpacticoids).

An interesting difference was observed in the vertical distribution of the fauna between the samples from March station "a" collected on 28.09.1973 and those on the 17.10.1973 (fig. 12 and table 5).

In September, the water level of the Danube drops; at the beginning of October it rises due to rainfall. In the samples from September, the total fauna and the main hypogean and epigean animals are distributed in the $1.35 \mathrm{~m}$ layer, this is the case for the amphipods, ostracods, cyclopoids; only the nematodes, harpacticoids and the oligochaetes are more abundant in the upper layer $(0.50$ m). In October the total fauna as well as the most important animal groups (amphipods, cyclopoids, harpacticoids, nematodes, oligochaetes and insect larvae) occur in the upper layer $(0.50 \mathrm{~m})$. It is difficult, at present, to explain these differences, but migration within the interstitial system, and penetration of new surface animals into the upper sediment layers seems to be a plausible hypothesis. For the oligochaetes, nematodes and cyclopoids a new invasion from the river could explain the increased number in the upper layers (table 5).

\section{REMARKS ON THE LIMNOHALACARIDS DIŠTRIBUTION}

Schwoerbel (1961a) and Husmann (1966) considered that the riverine interstitial habitat could be divided into two ecological zones i.e. "Hydrachnellen Zone" (the upper layers) and the "Limnohalacariden Zone" (the deeper layers). At the point at which limnohalacarids disappear, according to Husmann (1966), the true groundwater habitat, the eustygal, begins. This assumption is based on the fact that up to date the limnohalacarids have seldom been found in wells remote from the river shore (Husmann and Teschner, 1971). The faunistical

\footnotetext{
*) The hypogean isopod Proasellus slavus occurs also in wells remote from the Danube river, in the
} Tulln area (F-1246, F-1284, Donau-Che-6, see table 2 for the location of the wells). 
investigations carried out on the wells from Krems-Thallern, Moosbrunn (Piesting) and Wien (Danube) in lower Austria showed that the limnohalacarids occur sometimes in quite important numbers. In the area Krems-Thallern in the Danube Valley, the limnohalacarids were found in 3 wells located at distances varying from about $200 \mathrm{~m}$ (well $\mathrm{nr}$. 1332) to about $750 \mathrm{~m}$ (well $\mathrm{nr}$. 1324) (fig. 14). Both epigean and hypogean species have been found as in the Danube riverine sediments ( $W$. weberi, S. chappuisi and P. parviscutatus). The highest number of limnohalacarids occur in the well nr. 1326 which is located at about $600 \mathrm{~m}$ remote from the Danube shore; here 36 specimen were found. From the total number of specimen caught in the wells from area Krems-Thallern ( 48 specimen) $75 \%$ are $P$. parviscutatus, $18.75 \% S$. chappuisi and only $6.25 \%$ represent $W$. weberi. In a well from Moosbrunn at $12 \mathrm{~m}$ away from the Piesting and in a well from Vienna (F3) $400 \mathrm{~m}$ remote from the Danube) $W$. weberi ( 2 specimens) were found. This result invalidates the possibility of differentiating the eustigal from the rhitrostygal, using the limnohalacarids as bioindicators.

\section{THE DISTRIBUTION OF THE FAUNA IN CONNECTION WITH THE POLLUTION OF THE RIVER}

In lower Austria upstream from Vienna the water quality of Danube has degree of 2. In Vienna and downstream as far as the border, the water quality degree varies from 2-3 to 4 .

The hypogean fauna has been found in sediment banks where the Danube has a water quality degree of 2 (Melk, Tulln, Wien-Floridsdorf), 2-3 (March), 4 (Fischamend) (see the previous chapter). In the station Wien-Reichsbrücke, situated downstream from the sewage channels of Floridsdorf, the Danube has a water quality of 2-3. However, the interstitial water in the investigated area (fig. 3) is generally black suggesting a marked pollution of the interstitial habitat. Only epigean fauna was found in this station (fig. 10C, D, E), in samples from point "a", in superficial and deeper layers $(0.45 \mathrm{~m}$ and $1.5 \mathrm{~m})$, and in superficial layers from point " $b$ " $(0.60 \mathrm{~m})$. In the point " $a$ ", situated in a sheltered area close to the shore $(0.50 \mathrm{~m}$ distance $)$, the superficial layers contained a rather high number of animals (fig. 10C), mostly nematodes, oligochaetes and cyclopoids. In the deeper layers, the number of animals is much lower (fig. 10D). In the point " $b$ ", situated in more direct contact with the main river flow, the fauna is poor, only some nematodes and cyclopoids (fig. 10E). Neither hypogean nor epigean fauna occur in deeper layers from Reichsbrücke, point " $\mathrm{b}$ " (1.20 m depth) and March point "a" at $3 \mathrm{~m}$ depth (samples from 1973). In both cases, evident signs of chemical reduction have been found (large amounts of black detritus, water smelling of $\mathrm{H}_{2} \mathrm{~S}$ ). At this last station, accumulation of fatty substances (most probably mineral oil) was also observed. In Wien-Reichsbrücke, in the deeper layers at point " $b$ ", a large number of empty both adults and juveniles carapaces belonging to the hypogean ostracods Kovalevskiella sp. and C. kieferi were found. It is possible that the increasing pollution at this station eliminated the hypogean ostracods. Kovalevskiella sp. occurs in the deeper layers (1-1.20 m) of sediment from Wien- 
Floridsdorf (table 3). Then in August 1974 the interstitial water from the latter station has an oxygen content of $3.8 \mathrm{mg} / 1$ in $0.70 \mathrm{~m}$ depth, and at Reichsbrücke in $0.80 \mathrm{~m}$ depth, only $0.4 \mathrm{mg} / \mathrm{l}$ (the Danube water, at both stations, has a content of $8.7 \mathrm{mg} / \mathrm{l}$ ).

In Fischamend, despite the marked river pollution (water quality degree 4), hypogean amphipods were found (fig. $8 \mathrm{~K}$, L). The interstitial water of this station is brown and no signs of chemical reduction similar to those found in Reichsbrücke were observed. The pollution of the Piesting in the area of Moosbrunn is also rather high (water quality degree 3, the stream bed is covered with Sphaerotilus natans). At $0.70 \mathrm{~m}$ under the stream bed a rich fauna was found (fig. 11E). The presence of high numbers of hypogean animals, like harpacticoids (Parastenocaris $\mathrm{sp}$. - 66 specimen and Nitrocrella sp. (1 specimen), det. Prof. Löffler), ostracods (Mixtacandona sp. aff. transleithanica), syncarids (Bathynella sp.), nematodes (Stenonchulus troglodytes, Eder, 1975) is striking. It should be pointed out that the number of the Coli and coliforme bacteria decreases from 100000 cells $/ \mathrm{ml}$, in the surface water, to 3750 cells $/ \mathrm{ml}$ (det. Dr. Jaksch) in the sediments at $0.60 \mathrm{~m}$ depth. In the case of Piesting, the filtration process by the sediments and by the Sphaerotilus natans seems to be the main factor allowing the maintenance of a rich interstitial fauna, with many hypogean elements. Liebmann (1960) has already pointed out the importance of Sphaerotilus natans in the filtration process of the riverine water.

These data show that localised high pollution of the interstitial system (as in Wien-Reichsbrücke and March point "a" at $3 \mathrm{~m}$ depth) may also be present in areas where the river has not a too bad water quality degree (2-3).

One can conclude that only high pollution inside the interstitial habitat eliminates the hypogean fauna and the epigean fauna disappears mainly in those areas with marked chemical reducing conditions.

\section{SUMMARY}

The interstitial fauna living in the riverine sediments of the Danube and Piesting have been investigated in Lower Austria. The nematodes, oligochaetes and cyclopoids are the most abundant groups (they represent up to $80 \%$ of the total fauna). The harpacticoids, the insect larvae, the isopods, the amphipods, the cladocera and the limnohalacarids are poorly represented (generally under $20 \%$ of the total fauna). The absence of hydrachnellids is striking. The vertical distribution of the interstitial fauna shows for several groups i.e. limnohalacarids, ostracods, isopods, harpacticoids, that the epigean species are quantitatively better represented in the upper sediment layers instead of the hypogean species which are more abundant in the deeper layers. At one of the sites where samples were taken down to $3 \mathrm{~m}$, most of the interstitial fauna was concentrated in the upper $1.50 \mathrm{~m}$. The occurrence of limnohalacarids in the wells from the Danube Valley and the Piesting area shows that the repartition of this group is not restricted to the rhitrostygal zone. The distribution of the interstitial fauna in connection with the pollution of the river is discussed. High pollution inside the interstitial habitat eliminates the hypogean fauna and the epigeans disappear mainly in those areas with marked chemical reducing conditions.

\section{RÉSUMÉ}

La faune interstitielle dans les sédiments alluvionaires le long des rivages du Danube (en Basse Autriche) ainsi que sous le lit du ruisseau Piesting a été étudiée. Les Nématodes, les Oligochètes 
et les Cyclopoides sont les groupes les plus abondants. Ils représentent jusqu'à $80 \%$ de la faune totale. Les Harpacticoides, les larves d'Insectes, les Isopodes, les Amphipodes, les Cladocères et les Limnohalacarides sont faiblement représentés, en général en des sous de $20 \%$ de la faune totale. Il est à remarquer l'absence des Hydrachnelles.

La distribution verticale de la faune interstitielle montre pour certains groupes d'animaux (Limnohalacarides, Ostracodes, Isopodes, Harpacticoides) que les espèces épigées sont quantitativement mieux représentées dans les sédiments superficiels et les espèces hypogées dans les sédiments profonds. Dans une des stations ou des échantillons de faune interstitielle ont été prélevés jusqu'à $3 \mathrm{~m}$ de profondeur, on remarque que la majorité de la faune est concentrée dans les sédiments superficiels (jusqu'à $1,50 \mathrm{~m}$ de profondeur). La découverte de Limnohalacarides dans les puits de la Vallée du Danube et du Piesting suggère que ce groupe n'est pas strictement limité à la zone du rhitrostygal. La distribution de la faune interstitielle en fonction de la pollution de la rivière est discutée. Une forte pollution à l'interieur du système interstitiel peut éliminer la faune hypogée, tandis que la faune d'origine épigée est éliminée surtout dans les zones ou des conditions de réduction chimique sont présentes.

\section{REFERENCES}

AN DER LAN, H. 1962. Zur Turbellarienfauna der Donau. Arch. Hydrobiol. Suppl. 27: 3-27. ANDRASSY, I. 1962. Nematoden aus dem Ufergrundwasser der Donau von Bratislava bis Budapest. Arch. Hydrobiol. Suppl. 27: 91-117.

ANONYMUS 1970-1971. Biologisches Gütebild der Fließgewässer von Niederösterreich. Bundesministerium für Land- und Forstwirtschaft, Wasserwirtschaftskataster.

BOU, Cl. 1974. Les methodes de récolte dans les eaux souterraines interstitielles. Ann. Spéléol. 29, 4: 611-619.

BOU, Cl. \& ROUCH, R. 1967. Un nouveau champ de recherches sur la faune aquatique souterraine. C.R. Acad. Sci. 265: 369-370.

CASTANY, G. 1963. Traité pratique des eaux souterraines. Dunod, Paris, 717 p.

EDER, R. 1975. Zwei neue Funde von Stenonchulus troglodites Schneider 1940 (Onchulidae, Nematoda). Carinthia II, 165, 85: 291-294.

ERTLOVA, E. 1968. Die Mengen des Zoobenthos in den Schottern des Donaumedials. Arch. Hydrobiol. Suppl. 34, 4: 321-330.

FINK, J. 1967. Die Paläogeographie der Donau, in: LIEPOLT, R. ed. Limnologie der Donau 3: 1-50. Schweizerbart'scher Verlag, Stuttgart.

HUSMANN, S. 1966. Versuch einer ökologischen Gliederung des interstitiellen Grundwassers im Lebensbereich eigener Prägung. Arch. Hydrobiol. 62: 231-268.

HUSMANN, S. \& TESCHNER, D. 1970. Ökologie, Morphologie und Verbreitungsgeschichte subterraner Wassermilben (Limnohalacaridae) aus Schweden. Arch. Hydrobiol. 67, 2: 242-267.

LESCHER-MOUTOUE, F: 1973. Sur la biologie et l'écologie des Copépodes Cyclopoides hypogés (Crustacés). Ann. Spéléol. 28, 3: 429-502 et 4: 581-674.

LIEBMANN, H. 1960. Handbuch der Frischwasser- und Abwasser-Biologie II. 1-1149. R. Oldenbourg, Verl. München.

LIEPOLT, R. 1961. Limnologische Forschungen im österreichischen Donaustrom. Verh. Int. Ver. Limnolog. 14: 422-429.

LIEPOLT, R. 1972. Uses of the Danube River, in: OGLESBBY, R. T. ed. River, Ecology and Man: 233-251. Academic Press, N.-Y.

LÖFFLER, H. 1961. Grundwasser- und Brunnenostracoden aus Südwestdeutchland und den Vogesen. Beitr. naturk. Forsch. SW-Deutschlands 20: 31-42.

MOTAS, C., TANASACHI, J. et ORGHIDAN, Tr. 1947. Hydracariens phréaticoles de Roumanie. Notat. Biolog. 5: 3-67.

PONY, E. J. \& PONY, L. 1961. Daten über einige in dem interstitiellen Wasser der Donau lebenden Tiere bei Bratislava. Biologia Cas. Slov. Akad. Vied. 16: 838-841.

ROUCH, R. 1971. Peuplement par les Harpacticides d'un drain situé dans la zone de circulation permanente (Recherches sur les eaux souterraines, 14). Ann. Spéléol. 26, 1: 107-133. 
RUFFO, S. 1961. Problemi relativi allo studio della fauna interstiziale ipporeica. Biol. Zool. 28: 273-319.

SCHWOERBEL, J. 1959. Graeteriella uniseitiger (N. GRAETER 1908), ein seltener Cyclopoide (Crustacea, Copepoda) aus dem Grundwasser der versickernden Donau bei Möhringen. Mitt. bad. Landesver. Naturkunde u. Naturschutz, N.F. 7: 321-322.

1959. Zur Kenntnis der Wassermilbenfauna des südlichen Schwarzwaldes (Hydrachnellae, Acari). 5. Beitrag: Wassermilben aus dem Grundwasser. Mitt. bad. Landesver. Naturkunde $u$. Naturschutz 7: 323-330.

1961. Über die Lebensbedingungen und die Besiedlung des hyporheischen Lebensraumes. Arch. Hydrobiol. Suppl. 25: 182-214.

1961. Subterrane Wassermilben, ihre Ökologie und Bedeutung für die Abgrenzung eines aquatischen Lebensraumes zwischen Oberfläche und Grundwasser. Arch. Hydrobiol. Suppl. 25: 242-306.

1961. Neue und wenig bekannte Atractides-Arten aus dem hyporheischen Grundwasser (Acari: Hygrobatidae). Mitt. bad. Landesver. Naturkunde u. Naturschutz, N.E. 8: 41-63.

1962. Zur Kenntnis der Wassermilbenfauna des südlichen Schwarzwaldes. 6. Beitrag: Weitere Arten aus dem hyporheischen Grundwasser und aus Fließgewässern. Mitt. bad. Landesver. Naturkunde u. Naturschutz, N.E. 8: 251-260.

1964a. Fauna freatica din vecinatatea Dunarii (fauna hiporeica). Hidrobiologia (Bukarest) 5: 157-164.

1964b. Die Wassermilben (Hydrachnellae und Limnohalacaridae) als Indikatoren einer biocönotischen Gliederung von Breg und Brigach sowie der obsersten Donau. Arch. Hydrobiol. Suppl. 27: 386-417.

1967. Die stromnahe Fauna der Donau (hyporheische Fauna), in: LIEPOLT, R. ed. Limnologie der Donau: 284-294, Stuttgart.

VORNATSCHER, J. 1938. Faunistische Untersuchung des Lusthauswassers im Wiener Prater. Int. Rev. Hydrob. Hydrog. 37: 320-363.

1974. Die Tierwelt des Grundwassers - Leben im Dunkeln, in: Naturgeschichte Wiens II: 659-673. Jugend und Volk, Wien.

WASSER WIRTSCHAFTKATASTER, 1975. Grundlagen der Wasserwirtschaft Teil I, Wien und Umgebung Sachgebiet. Bundesministerium für Land und Forstwirtschaft Verl.

WILLIAMS, W. D. \& HYNES, H. 1974. The occurrence of benthos deep in the substratum of a stream. Freshwat. Biol. 4: 233-256. 